\title{
Evolution of infrastructure as an asset class: a systematic literature review and thematic analysis
}

\author{
Surbhi Gupta ${ }^{1}\left[\right.$. Anil Kumar Sharma ${ }^{1}$
}

Revised: 4 January 2022 / Accepted: 6 January 2022 / Published online: 1 February 2022

(c) The Author(s), under exclusive licence to Springer Nature Limited 2022

\begin{abstract}
Infrastructure as an asset class has emerged as a new field of research stemming from the broader universe of infrastructure investment. Since the advent of the global financial crisis, research activities in this area are constantly strengthening providing the base for a budding research area. Despite much work done, infrastructure investment research with regard to an asset class is still at an early stage and scholarly understanding remains restricted and fragmented. To get a clear understanding of this rather opaque field, and for further advancement of scientific research, we conduct a systematic literature review and thematic analysis of 89 scientific contributions including 71 journal articles, 15 working papers and 3 conference papers published during 1997-2021. Based on a holistic examination of identified articles, we elucidate the current infrastructure investment landscape targeting two major aspects: First, we descriptively analyse the convergence of infrastructure from mere assets to an asset class. Second, we categorize the existing research into four different perspectives: capital market, investment performance, policy and stakeholder and conduct a thematic analysis to unveil major themes and sub-themes under each perspective. Furthermore, the study attempts to suggest various promising future research avenues to encourage further expansion of infrastructure investment as a research field.
\end{abstract}

Keywords Systematic literature review $\cdot$ Thematic analysis $\cdot$ Infrastructure finance $\cdot$ Asset class

JEL Classification G12 $\cdot \mathrm{H} 54 \cdot \mathrm{C} 38 \cdot \mathrm{G} 23$

\section{Introduction}

Infrastructure is considered as the linchpin of economic growth of any nation. Although there is no generally accepted definition of infrastructure, OECD simply defines it as 'the system of public works in a country, state or region, including roads, utility lines and public buildings'. This definition emphasizes the physical characteristics of infrastructure, whereas in investment world, infrastructure is defined by its unique financial and economic characteristics. Stevens and Schieb (2007) categorize infrastructure in two major categories: economic and social, both of which are inevitable

Surbhi Gupta

sgupta2@bm.iitr.ac.in

Anil Kumar Sharma

anilsharma@ms.iitr.ac.in

1 Department of Management Studies, Indian Institute of Technology Roorkee, Roorkee, Uttarakhand 247667, India for an unhindered growth of a country. While economic infrastructure includes transport (airports, seaports, toll roads and railways), communications (broadcast facilities and cable networks) and utilities (electricity distribution and generation, gas distribution and storage, renewable energy and water distribution and treatment), social infrastructure includes healthcare, education and correctional facilities (Inderst 2010a). Due to rapid urbanization and climate change, demand for technologically advanced and environmentally sound infrastructure is rising more than ever. While developing nations are struggling to build basic infrastructure to promote foreign investment, developed nations are in dire need to replace their ageing infrastructure (Urban Land Institute and Ernst \& Young 2013).

The importance of infrastructure for a well-functioning economy is well recognized and so does the lack of investment in this sector. Several international organizations have provided estimates for a widening infrastructure investment gap. Woetzel et al. (2017) state that USD 69.4 trillion infrastructure investment is required globally across sub-sectors 
power, roads and telecommunications, OECD (2015) estimated infrastructure needs worth USD 50 trillion during 2013 and 2030 and a funding gap of around USD 1.5 trillion per annum, World Economic Forum (WEF) highlighted an investment gap of USD 1 trillion in infrastructure worldwide. Historically, infrastructure services have been mainly provided by central and state governments, where governments acted as finance providers, owners and operators of infrastructure projects. However, rising fiscal constraints have pushed the governments around the world to seek private sector participation to fund this investment gap. Consequently, large private players like institutional investors (including insurance companies, pension funds and sovereign wealth funds) are steadily emerging as potential finance providers to this sector (Inderst and Stewart 2014a). The reasons are manifold: First, rising non-performing assets (NPAs) restrict the ability of commercial banks to provide necessary financing to this sector. Second, infrastructure investments provide duration matching in accordance with the asset/liability requirements of institutional investors like pension funds and insurance companies (Inderst 2009; Della Croce and Yermo 2013). Third, post-GFC, most of the traditional asset classes faced negative absolute returns, increased volatilities and rising correlations, limiting their portfolio diversification potential (Oyedele 2014). Moreover, the focus of the governments shifted towards infrastructure development as a means to tackle severe recession and promote economic recovery, thus giving a major boost to this sector. Lastly, the amount of pension funds' savings worth USD 100 trillion is tied in low-yield fixed income securities (Çelik and Isaksson 2013), further lowering their returns. Therefore, institutional investors made their way towards alternative asset classes that are supposedly more resilient to financial shocks, provide stable cash flows and inflation protection (Della Croce and Gatti 2015). As a result, infrastructure received a large influx of capital from private investors-both institutional and retail (RREEF 2005) and became a topic of growing research interest among academicians and practitioners alike.

Although the literature in infrastructure financing dates back to as early as 1980 s, it has gained popularity as an investment alternative only in recent decades (Fig. 1).
Majority of the earlier research focused on contract-based financing approaches such as project finance initiatives (PFI) and public-private partnerships (PPP). However, inefficiencies like greater political risks, red tape and bureaucratic delays resulted in an unsuccessful track record of these traditional financing approaches. As a result, a need to shift from contract-based to market-based financing approaches was realized that provide an innovation-led investment alternative channelled via invisible hands of capital markets to finance large and complex infrastructure projects and is mutually beneficial for both investors and users alike (Chen 2002). According to Greer (1997), 'an asset class is a set of assets that bear some fundamental economic similarities to each other, and that have characteristics that make them distinct from other assets that are not part of that class.' Infrastructure assets possess some of the unique investment characteristics such as high barriers to entry resulting from huge upfront capital requirements, monopoly of state in provision of services, inelasticity of demand, long gestation periods of up to 99 years and wide heterogeneity across its sub-sectors (Inderst 2010a, 2016) that make them distinguishable from other assets. These characteristics have also attracted the interest of private investors looking for stable, inflation-linked cash flows in the long-run (Martin 2010). However, whether infrastructure is a separate asset class or is just another set of investment vehicles is still a topic of debate.

The evidence to date on whether infrastructure is a separate asset class or not is rather contradictory. However, the ongoing scientific discussion in various finance journals illustrates the contribution of this field to the larger investment finance universe (e.g. Journal of Property Investment and Finance, Financial Markets and Portfolio Management, Journal of Portfolio Management, The Journal of Structured Finance). Further, integration of research from areas like social sciences (Kalmykov 2015), public policy (Little 2010), economics (Clark et al. 2012) and management in engineering (Lu et al. 2019) highlights the multi-disciplinary character of this research field. Also, the contribution of infrastructure financing in non-property journals (e.g. Public Money and Management, Environment and Planning, Journal of Management in Engineering, Public Works
Fig. 1 Number of publications from 1997 to 2021. *Till March 2021. Source: Authors' compilation
Publications from 1997-2021*

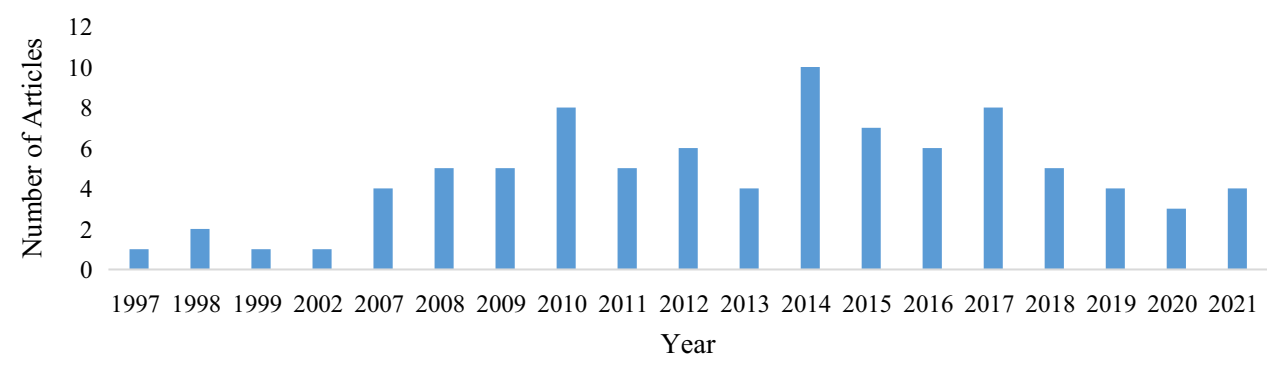


Management \& Policy) indicates the growing prominence of infrastructure financing outside the property finance arena.

Despite the growing importance of this field, research catering specifically to infrastructure in an asset class context is rather limited and fragmented which make synthesis of existing literature quite difficult and much needed. Much of the research in this field is industry-oriented and the contribution from academia has been rather slow. This literature gap also forms the motivation of present study which is to review, classify and synthesize the current body of literature systematically and provide a holistic view of infrastructure as an asset class. The study aims to answer the following research questions:

(1) How has infrastructure evolved as an asset class?

(2) What are the dominant themes that address infrastructure in an asset class context?

(3) What are the promising future research avenues that require attention?

For this, we use a hybrid approach combining systematic literature review and thematic analysis and conduct an in-depth examination of 89 scientific contributions. To the best of our knowledge, this is the first systematic review to examine infrastructure in an asset class context. Earlier literature reviews cater to specific infrastructure sub-sectors like water and sanitation (Machete and Marques 2021; Lima et al. 2021), public-private partnerships/project finance initiatives (Roehrich et al. 2014; de Castro e Silva Neto et al. 2016; Müllner 2017; Kumar et al. 2021) and infrastructure development in general (Kumari and Sharma, 2017). Although most of the earlier research focuses on economic infrastructure, the state of social infrastructure has gained much-needed attention during the COVID-19 crisis. In a recent study, Inderst (2020) provides a systematic account of financing and investment in social infrastructure from a global perspective. While this is an interesting area with significant research gaps, we have kept it out of scope of the present study as not much is available on the topic till date.

The contributions of the present study are twofold: Firstly, we add to the existing body of knowledge by providing a comprehensive view of infrastructure as an asset class. Secondly, we identify and classify the final contributions into dominant themes based on the issues addressed by them and provide potential directions for further advancement of this research field. Rest of the paper is organized as follows: In the second section, we outline the methodology used and lay down the process of conducting literature search and systematic review. Thereafter, we highlight the major findings of our systematic review process, including a summary of the scientific development of infrastructure as an asset class. We present the synthesized findings of the thematic analysis and provide potential research avenues towards the end of the paper. After that, we conclude our study along with limitations.

\section{Methodology}

To identify the relevant literature, we follow a multi-stage process of a systematic literature review as it provides desired replicability and transparency (Mulrow 1994). To provide a detailed overview of the scientific growth and budding research themes, we modify the systematic review to be built on a content-analysis based evaluation of research articles. In this way, we strengthen the process as given by Tranfield et al. (2003) using an inductive process of thematic analysis, which is generally used in qualitative psychology. The following sections describe the adaptation of these stages, modified as per our research questions.

\section{Planning the review}

At this stage, we define the search string used for the selection of relevant literature. We create the search string based on a combination of keywords used in previous studies such as 'infrastructure', infrastructure investment' or 'asset class'. We narrowed our search to look for search terms in either title, abstract or keywords. The following search string was used for the purpose:

("infrastructure" OR "infrastructure assets" OR "listed infrastructure" OR "unlisted infrastructure") AND (invest* OR financ*) AND ("asset class" OR "investment class" OR "institutional invest*" OR "portfolio" OR "asset allocation" $O R$ "asset pricing" OR "pension fund" OR "insurance companies" OR "capital market" OR "stock market")

To ensure lucidity, we base our selection of research articles on pre-defined inclusion and exclusion criteria (Tables 1 and 2, respectively). Our sample dataset comprises published scientific contributions only, e.g. journal articles, working papers and conference papers. The present study excludes case studies, books, book chapters, commentaries, industry reports and editorials due to limited availability (Liñán \& Fayolle 2015). Also, we have excluded the scientific contributions catering to traditional infrastructure financing approaches like project finance and public-private partnerships (PPP) to keep infrastructure as the focus of our study, typically, as an asset class. To ensure transparency, we follow a detailed literature search protocol (Table 3).

\section{Conducting the review}

The process comprises three stages (plan, conduct and report) as defined in the seminal work of Tranfield et al. (2003). In the first step, we conduct a thorough electronic databases search in Scopus, EBSCOHost-Business Source 
Table 1 Inclusion criteria

\begin{tabular}{lll}
\hline No. & Criteria & Reason \\
\hline 1 & Theoretical scientific contributions & Provides a foundation to understand any emerging research field \\
2 & Qualitative/Quantitative empirical studies & Present empirical evidence and help in getting an in-depth understanding of the area \\
3 & $\begin{array}{c}\text { Published journal articles, working papers, and } \\
\text { conference proceedings }\end{array}$ & Infant research areas are usually dominated by working papers and conference papers \\
& No restricted focus on financial databases & Infrastructure financing is a multi-disciplinary field \\
5 & Scientific papers till March 2021 & Most recent coverage \\
\hline
\end{tabular}

Table 2 Exclusion criteria

\begin{tabular}{lll}
\hline No. & Criteria & Reason \\
\hline 1 & Thesis of research scholars available online & Focus on scientific contributions \\
2 & No exact synonym or phrase in either Title, Abstract, Keywords & $\begin{array}{l}\text { Ensure articles fall within the scope of umbrella term infrastructure } \\
\text { financing } \\
\text { Excluded all the publications which are not written in English language } \\
\text { (addressing to mass audience) }\end{array}$ \\
3 & Foreign language & $\begin{array}{l}\text { Bibliometric principle (Glänzel 2003) } \\
\text { To ensure the inclusion of studies addressing infrastructure in an asset } \\
\text { class context only }\end{array}$ \\
5 & $\begin{array}{l}\text { Duplications } \\
\text { PPP / Project finance related scientific contributions }\end{array}$ & $\begin{array}{c}\text { Limited availability and fragmented } \\
\text { Case studies, books, book chapters, commentaries, industry } \\
\text { reports, and editorials }\end{array}$ \\
\hline
\end{tabular}

Table 3 Research guidelines

\begin{tabular}{llllll}
\hline Publisher & Database & $\begin{array}{l}\text { Number of contribu- } \\
\text { tions based on search } \\
\text { string }\end{array}$ & $\begin{array}{l}\text { Number of contributions } \\
\text { included based on: inclusion } \\
\text { criteria }\end{array}$ & $\begin{array}{l}\text { Number of contributions } \\
\text { included based on: exclusion } \\
\text { criteria }\end{array}$ & $\begin{array}{l}\text { Total number of relevant } \\
\text { contributions }\end{array}$ \\
\hline Elsevier & Scopus & 2012 & 168 & 87 & 87 \\
Ebsco Host & $\begin{array}{c}\text { Business } \\
\text { source } \\
\text { ultimate }\end{array}$ & 1589 & 21 & 2 & $\begin{array}{c}89 \text { (71 journal articles, } 15 \\
\text { working papers, and 3 } \\
\text { conference papers) }\end{array}$ \\
\hline
\end{tabular}

Ultimate and Web of Science as they cover majority of literature in various areas. Our search is focused only on peerreviewed scholarly journal articles, conference papers and working papers published during 1997-2021 ${ }^{1}$. The search string initially resulted in 3601 contributions which were further narrowed down on the basis of database filters such as language (English), document type (peer-reviewed journals, working \& discussion papers, conference papers) and subject areas (business, management, economics, econometrics and social sciences). To keep infrastructure investment as the focus of our study and to eliminate irrelevant articles, a thorough screening of articles was done based on their

\footnotetext{
${ }^{1}$ Given the less number of studies in this area, we decided to conduct an "open" search without a start date, so as to capture a fair picture of the current state of knowledge, including earliest publications. The oldest article found during our search was published in 1997.
}

titles, abstracts and keywords. After removing duplicates and applying inclusion and exclusion criteria, 89 final contributions are included for detailed examination, including 71 journal articles, 15 working papers and 3 conference papers.

\section{Data synthesis}

Following Jones et al. (2011), we use an inductive, evaluation-based approach to identify inherent themes and subthemes in the dataset. The concept of thematic analysis emerges from psychology and provides a useful 'method for analysing and reporting patterns in data' (Braun and Clarke 2006) where a theme demonstrates the elementary concepts of analysed data. Consequently, each theme indicates the nature of its content, representing fundamental ideas and premises resulting from particular research questions and objectives (Thorpe et al. 2005). 
Fig. 2 Distribution of published articles in various journal areas
Published articles in broad journal areas

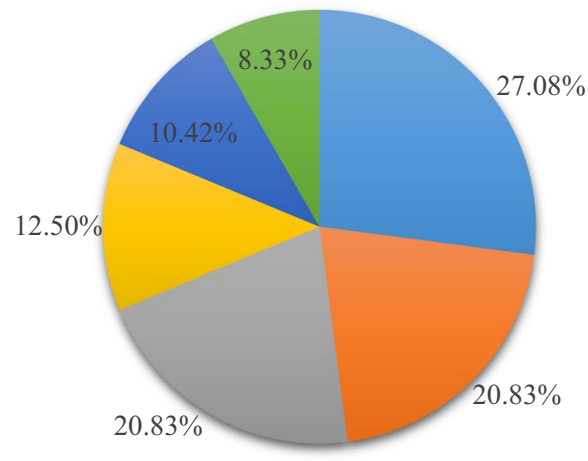

$\varpi$ Finance $\square$ Economics $\square$ Engineering, science and technology $\square$ Other $\square$ Social sciences $\square$ Property

To mitigate subjectivity, we based the classification and selection of relevant publications on the combined judgement of the authors. Any inconsistencies in the identification of themes were discussed and adjustments were made accordingly. In case a study addressed more than one theme, we based our decision on the stated aim of the paper for classification and categorization (Liñán and Fayolle 2015). To present a thematic landscape, we categorize the relevant publications in four major perspectives: Capital Market Perspective, Investment Performance Perspective, Policy Perspective and Stakeholder Perspective.

\section{Reporting the findings}

In this section, we use a two-stage process to synthesize the existing literature. First, we present an overview of the scientific development of infrastructure as an asset class and descriptively analyse the current state of knowledge. Second, we elaborate the findings of our thematic analysis and conclude our study by reporting the implications and potential future research directions.

\section{Descriptive analysis of infrastructure financing research}

Earlier studies use geographical coverage and methodologies as parameters to identify trends in the literature (e.g. Tranfield et al. 2003; Macpherson and Holt 2007). Present study descriptively analyse the sample dataset using similar criteria modified as per our research questions.

\section{Development of the existing body of knowledge}

Infrastructure as an asset class gained much attention during the Global Financial Crisis (GFC) of 2008 as illustrated by a wide range of publication formats, such as journal articles, books, working papers and case studies. Literature search used in the present study resulted in a final dataset of 89 scientific contributions. Journal articles spread through a wide array of 48 different journals highlighting the multidisciplinary nature of this research field. Various journals publishing infrastructure financing research are summarized in Fig. 2 by their focus areas, and Table 4 summarizes the distribution of studies published specifically in finance and property, economics and engineering, science and technology journals, being the dominant areas in respective panels.

\section{Conferences on infrastructure financing}

In addition to journal articles, we also found three conference papers in Proceedings of Institution of Civil Engineers: Management, Procurement and Law, The Societal Function of Investment Asset Classes: Implications for Responsible Investment Conference, and 50th Annual Transportation Research Forum. Two of the conferences cater to engineering and transportation systems which are very different research areas from property and finance, which infrastructure financing is majorly a part of.

\section{Geographical coverage}

Geographically, majority of the publications study infrastructure as an asset class with a global focus $(27.47 \%)$, followed by three dominant regions: Europe, USA and Australia which is not surprising as they are the markets leaders in privatization of infrastructure assets. Within Europe, UK is the most focused region with around $58 \%$ of the studies catering to it. Another interesting observation is that $12.36 \%$ of studies focus on emerging markets, $2.25 \%$ cater to Asia and only $1.12 \%$ are based on Africa. Within emerging markets, India, Brazil and China are the most popular countries (Table 5). 
Table 4 Published articles in finance and property journals

$$
\text { Journal }
$$

Number of articles published

Panel A: Finance and property journals

Journal of property research 7

Journal of Property Investment and Finance

Pacific Rim Property Research Journal

Public Money and Management

The Journal of Structured Finance

Financial Markets and Portfolio Management

Journal of Portfolio Management

Journal of Alternative Investments

Journal of Financial Management of Property and construction

International Journal of Financial Studies

Pacific-Basin Finance Journal

Journal of Real Estate Portfolio Management

Panel B: Economics journals

Pensions

Environment and Planning A

Cogent Economics and Finance

Economic Geography

Panel C: Engineering, science and technology journals

Public Works Management and Policy

International Journal of Scientific and Technology Research

Journal of Management in Engineering

Engineering, Construction and Architectural Management

$\begin{array}{ll} & 2 \\ & 1 \\ & 1 \\ & 1\end{array}$

\begin{tabular}{ll}
\hline Region & Total (\%) \\
\hline Global & 28.09 \\
Europe & 13.48 \\
UK (58.33) & \\
USA & 14.61 \\
Australia & 10.11 \\
Asia & 2.25 \\
Emerging markets & 12.36 \\
India (18.18) & \\
Brazil (9.09) & \\
China (18.18) & \\
Canada & 2.25 \\
Africa & 1.12 \\
Others & 15.73 \\
Total & 100 \\
\hline
\end{tabular}

Table 6 Methodologies applied

Table 5 Geographical coverage

\section{Methodological information}

\begin{tabular}{lc}
\hline Method & Total (\%) \\
\hline Quantitative & 44.94 \\
Descriptive statistics (97.50) & \\
Regression (OLS) (2.50) & 48.35 \\
Qualitative & \\
Descriptive (65.12) & \\
Interview-based studies (6.98) & \\
Mixed methods (13.95) & \\
Literature review (6.98) & \\
Survey (6.98) & 6.71 \\
Conceptual & 100 \\
Total &
\end{tabular}

financing research. $97.50 \%$ of quantitative studies apply descriptive statistics and portfolio optimization techniques in a broad statistical framework. Data for most of the empirical studies are sourced from Thomson Reuters and Bloomberg. For unlisted infrastructure research, Australia is the most preferred nation being the sole provider of the relevant data. Very few studies source data from local authorities of emerging countries like India, Brazil, China and Indonesia. 
Further, qualitative studies employ literature reviews, surveys and expert interviews as preferred methods of analysis. For the purpose of expert interviews, expert opinions are sourced from infrastructure funds' industry and public policy domain. Majority of qualitative studies $(65.12 \%)$ are descriptive in nature.

\section{Observations and implications}

Looking at the trends in literature, we emphasize that infrastructure as an asset class is still at an early stage with most of the work being developed on theoretical grounds only. As the infrastructure investment gap widened, infrastructure financing became a major concern and focus of scientific discussion. The rising number of publications in peerreviewed journals of engineering, science and technology, environment and social sciences highlights the growing prominence of infrastructure financing inside and outside the limited context of property and public policy. As a subfield of investment finance, infrastructure investment caters to various concepts (e.g. public policy, alternative investments, institutional investment) and leads to new research areas. It is not surprising that most of the studies in our sample are published in property finance and economics journals (35.41\% and 20.83\% respectively); however, some of the leading investment finance journals (e.g. The Review of Financial Studies, Journal of Finance, Journal of Financial Economics, and Journal of International Money and Finance) are still uncovered. One apparent reason for this could be the multi-disciplinary nature of this field. In general, finance journals entertain more disciplinary focused research and tend to reject inter-disciplinary research such as public policy and money management. However, this may lead to under-development of scientific research in this area as infrastructure is steadily turning into an asset class.

Despite the unfamiliarity of this research field, the diversity in empirical research is somewhat surprising. Numerous empirical papers analyse the performance of infrastructure investments considering it a separate asset class, thus serving as a base for promoting further research in this field. However, majority of the empirical studies are based only on listed infrastructure data. Only a handful of studies examine direct or unlisted infrastructure owing to data limitations. Infrastructure investments are characterized by interactions among various stakeholders, unique investment features, uncertain regulatory environment and contractual complexities which makes this area well suited for a comprehensive analysis.

\section{Thematic analysis}

In this section, we present the main findings of the thematic analysis. To provide a comprehensive and coherent view, we discuss our findings along each identified perspective. The entire dataset is initially divided into four major themes: Capital Market Perspective, Investment Performance Perspective, Policy Perspective and Stakeholder Perspective. We examine each theme in detail and highlight the potential research avenues.

\section{Capital market perspective}

Under this theme, majority of the studies included are qualitative in nature and focus on the theoretical aspect of how the potential and development of well-functioning capital markets can help in better channelization of investors' savings to infrastructure projects, with a special focus on debt financing. In total, we assign 8 studies (Table 7) to this theme further sub-divided into two sub-themes: marketbased financing and asset backed securitization.

\section{Market-based financing}

Adopting a review approach, Regan (2017) finds strong positive associations between capital market development, infrastructure investment and economic growth. To exploit the full potential of new financing methods including asset recycling, increased private participation, and wider use of taxexempt and revenue bonds, there is a need to develop and deepen capital markets in the Asia-Pacific region. The prolonged infrastructure investment gap in the region is a major impediment to greater regional collaboration and trade. In earlier studies, Chen (2002) and Chen and Kubik (2007) also present the shortcomings of traditional approaches to finance infrastructure in the Asia-Pacific region. Chen (2002) highlights the pitfalls of two major traditional modes, i.e. state-owned projects and FDI-based financing. While state-owned projects are prone to inefficient bidding process, red tape and corruption, FDI-based financing methods suffer from exchange rate risks, political instability and delays in approval processes. Chen and Kubik (2007) analyse the issues associated with contract financing approaches prevalent in India. The authors adopt a conceptual approach and identify managerial inefficiencies, concentration, liquidity, and political risks as some of the most common impediments associated with popular approaches of Public-Private Partnership (PPP) and Build-Operate-Transfer (BOT). Furthermore, the authors suggest a financing approach guided by capital markets to finance complex infrastructure projects. They emphasize that this approach will lead to more private sector involvement and provide benefits like diversification, reduced burden on banking system, adequate liquidity, boost institutional investors' confidence and accurate project evaluation.

Some studies focus on the debt financing aspect of capital market. Vassallo et al. (2018) employ SWOT analysis 
Table 7 Capital market perspective

\begin{tabular}{|c|c|c|c|}
\hline Author(s) & Research issue & Research design & Data \\
\hline \multicolumn{4}{|l|}{ Market-based financing } \\
\hline Vassallo et al. (2018) & $\begin{array}{l}\text { Illustration of constraints and attractiveness } \\
\text { of the Project Bond Initiative (PBI) within } \\
\text { Europe. }\end{array}$ & Qualitative; SWOT analysis & n. a \\
\hline Gawlitta and Kleinow (2015) & $\begin{array}{l}\text { Examines the emergence of infrastructure debt } \\
\text { funds in EU. }\end{array}$ & Conceptual & n. a \\
\hline Kalmykov (2015) & $\begin{array}{l}\text { Examines the role of infrastructure bonds in } \\
\text { Russia }\end{array}$ & Conceptual & n. a \\
\hline Chen (2002) & $\begin{array}{l}\text { Analysis of the problems associated with tradi- } \\
\text { tional infrastructure financing approaches. }\end{array}$ & Conceptual & n. a \\
\hline Chen and Kubik (2007) & $\begin{array}{l}\text { Proposes a global capital market approach for } \\
\text { infrastructure financing in India. }\end{array}$ & Conceptual & n. a \\
\hline Regan (2017) & $\begin{array}{l}\text { Examination of inter-relationships between } \\
\text { infrastructure investment, capital markets, and } \\
\text { economic growth }\end{array}$ & Qualitative; literature review & n. a \\
\hline \multicolumn{4}{|l|}{ Asset-backed securitization } \\
\hline Lu et al. (2019) & $\begin{array}{l}\text { Construction of an assessment framework for } \\
\text { financing PPP infrastructure projects via } \\
\text { asset-backed securitization }\end{array}$ & $\begin{array}{l}\text { Qualitative; literature } \\
\text { review, case study and } \\
\text { expert interviews }\end{array}$ & $\begin{array}{l}119 \text { responses from industry } \\
\text { practitioners in China }\end{array}$ \\
\hline Dong et al. (2010) & $\begin{array}{l}\text { Proposes a new project-backed security (PBS) } \\
\text { setting to distribute risks fairly. }\end{array}$ & $\begin{array}{l}\text { Quantitative; multi-linear } \\
\text { regression with Monte } \\
\text { Carlo simulation }\end{array}$ & Hypothetical numerical examples \\
\hline
\end{tabular}

to assess the constraints and attractiveness of Project Bond Initiative (PBI) launched in Europe. Despite the regulatory constraints in Europe imposed by Basel III norms, dwindling credit rating market after the GFC, authors maintain a positive outlook towards PBI and reinforce the potential of institutional investors in bridging the infrastructure investment gap. PBI is expected to result in a strengthened bond market provided certain challenges are tackled first. Gawlitta and Kleinow (2015) provide an overview of European infrastructure debt funds' market. The authors opt a different perspective and caution that infrastructure investment boom may end sooner than expected. Due to cash flow projections of infrastructure projects and unregulated lending by infrastructure debt funds, more stringent regulatory norms are bound to be implemented leading to an end of all these activities. Authors suggest an alternative approach of issuing less risky project bonds with state guarantees for financing infrastructure projects in Europe. Kalmykov (2015) descriptively assesses the suitability of infrastructure bonds as an investment option in pension funds' portfolios. The author suggests an investment of up to $65 \%$ in infrastructure bonds (across sub-sectors) by pension funds and remainder in other instruments like corporate bonds, shares and direct investments to achieve diversification and profitability.

\section{Asset-backed securitization}

We find only two studies focusing on securitization of infrastructure investments. Lu et al. (2019) conducted a qualitative study using a combination of literature reviews, case studies and expert interviews to analyse PPP asset-backed securitization (ABS) as a financing mechanism for infrastructure projects. The author identified 25 critical success factors and then collected opinions from stakeholders involved in the PPP financing structure and experts from capital markets. Five broad dimensions including clear regulatory guidance, robust PPP and concessional arrangements, reliable underlying asset quality, effective ABS issuance and lifetime management, and efficient capital market conditions were identified and used to construct an assessment framework to evaluate the potential of ABS financing as an effective method to finance PPP projects. Dong et al. (2010) analyse the feasibility of securitizing revenue streams generated from brownfield infrastructure projects as a method to finance greenfield projects. The author proposes a pricing mechanism for new kind of project backed securities (PBS), i.e. revenue performance-linked PBS embedded with call and put options to allow both investors and issuers a riskhedging ability against two major risks, interest rate changes and irregular revenue streams. 


\section{Discussion and future research prospects for capital market perspective}

6 out of 8 contributions in this category assess the viability market-based financing approaches and only two publications cater to asset-backed securitization. Both the studies (Dong et al. 2010; Lu et al. 2019) talk about asset-backed securitization as an alternative financing option for infrastructure projects; however, none of them addressed how this could actually work with real world infrastructure projects. Scholars could examine empirically how to assess the financial performance of projects funded through asset-backed securitization? What factors influence investors to invest in project-backed securities? Studies by Chen (2002) and Chen and Kubik (2007) descriptively present how invisible hands of capital markets along with financial innovation can prove to be a better alternative than contract-based financing approaches like BOT and FDI. However, we strongly support their notion that well-functioning capital markets and financial innovation are pre-requisites for raising finance through capital markets. Where capital markets in developed nations are well suited to handle complex investment products like asset-backed securities, emerging markets still lag behind in dealing with complex derivatives due to vast inherent volatility and relatively unstable environment. Furthermore, raising finance through project bonds with event risk provisions and project stocks with contingent value rights require a sophisticated derivatives market which is free from insider trading and security manipulation. More precisely, how emerging markets could benefit from their relatively resilient capital market in raising much-needed infrastructure finance?

Few studies (Kalmykov 2015; Vassallo et al. 2018) conclude that infrastructure project bonds present a promising financing option; however, there are many challenges that need to be tackled first such as striking a trade-off between benefits to investors and taxpayers, contractual adjustments required as per the needs of institutional investors, minimizing the impact of construction and inflationary risks on investors' return. However, majority of the studies focus on the European region and it would be noteworthy to assess the viability of infrastructure bonds in other regions as well.

\section{Investment performance perspective}

One of the major reasons for a subdued investment by institutional investors in infrastructure is lack of knowledge regarding its performance and benchmarking. Various studies have attempted to fill this gap and assessed the investment performance of infrastructure as an asset class. We have categorized 38 contributions under this perspective that empirically investigate the most popular investment characteristics of infrastructure investments. This is one of the largest and important dimensions of the present study as it aids investor decision making and boost investors' confidence while investing in a relatively new asset class. The studies are further categorized into four sub-themes: analysis of investment attributes of listed infrastructure vehicles, investment attributes of non-listed infrastructure vehicles, factor models to explain infrastructure returns and inflation hedging ability of infrastructure investments (Table 8).

\section{Investment attributes of listed infrastructure vehicles}

This comprises the largest sub-theme under investment performance perspective. 22 out of 38 studies use listed infrastructure data to empirically examine the performance of infrastructure investments. Some studies recognize the inherent heterogeneity of infrastructure and analyse it subsector-wise. For instance, Marzuki and Newell (2021a) assess telecommunication due to the growing need for technology-driven and information-led infrastructure. The authors empirically assess the risk-return performance of listed satellite and telecommunication infrastructure over a nineteen-year timeframe and found mixed investment performance. The sector depicts high risks and suboptimal returns during the GFC, but delivers a strong performance post-GFC when compared to other asset classes. Additionally, using mean-variance optimization, the study shows enhanced portfolio diversification benefits when listed communication is added to a multi-asset portfolio. In contrast, Chakkalakal et al. (2018) found no significant portfolio diversification benefits by transport sub-sector. The authors suggest that this investment class is suitable for investors with high risk high return preference. However, they observe that transport does not move in tandem with the overall market and certainly does not exhibit the same investment characteristics as overall infrastructure. Balatbat et al. (2010) compare the performance of 30 listed construction companies with non-construction companies of Australia. Using fundamental analysis, the authors find a comparable performance exhibited by construction companies on a set of performance and financial indicators. The only time they performed sub-optimally was during the introduction of Goods and Services Tax (GST) in 2000. Satta et al. (2017) empirically evaluates the long-term performance of IPOs issued in seaports industry across the globe. Since 2000, the performance of 93 port-related IPOs was analysed using Ordinary Least Squares (OLS) regression analysis. Impact of various macroeconomic variables such as financial market, institutional and industry specific factors is observed on the long-term performance of IPOs. Authors found a significant explanatory power exhibited by the above-mentioned factors. Although the sample IPOs reflected a staggering performance on their first trading day, authors argue that quasimonopolistic and stable cash flow characteristics of port 


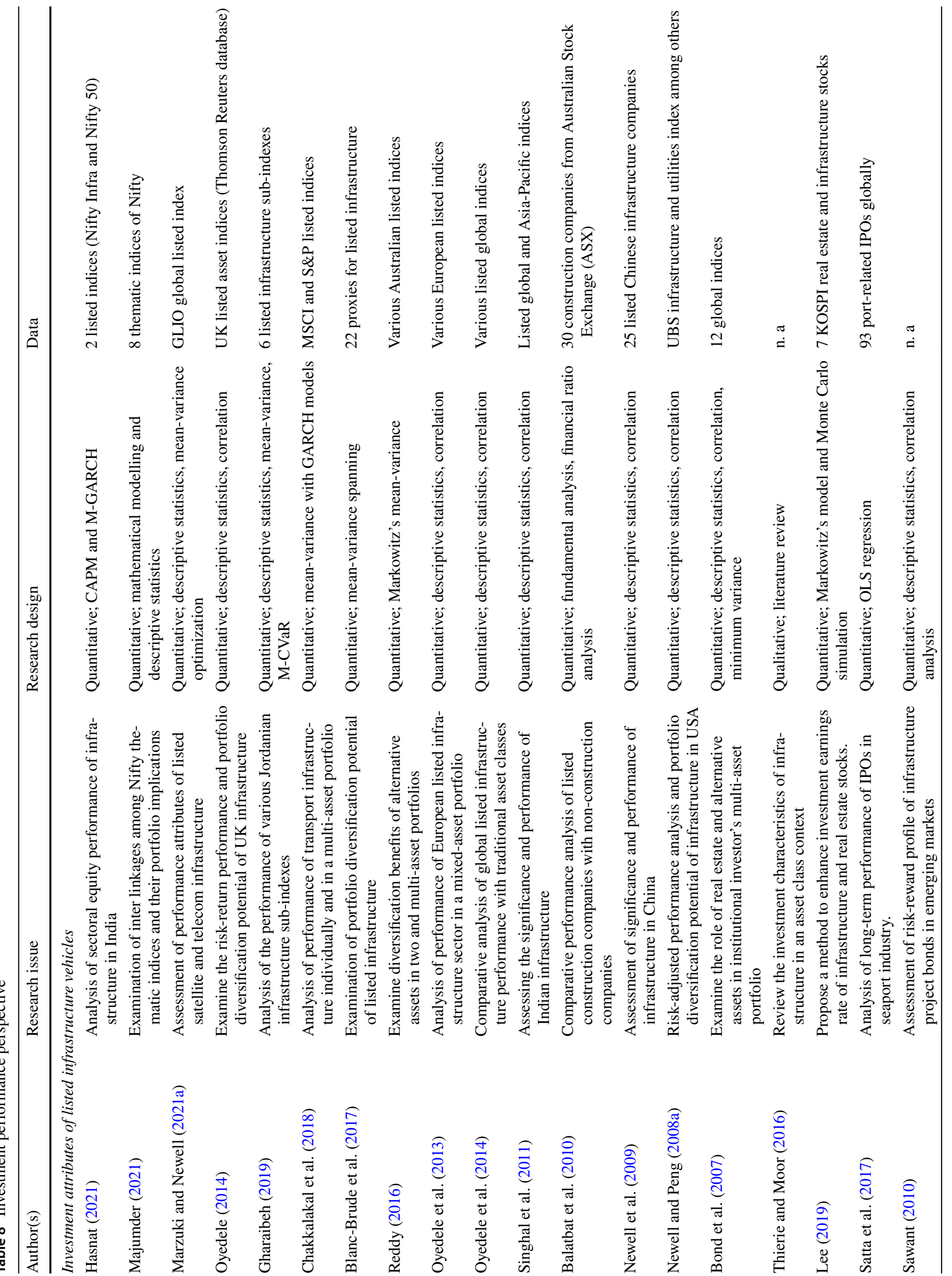

就 


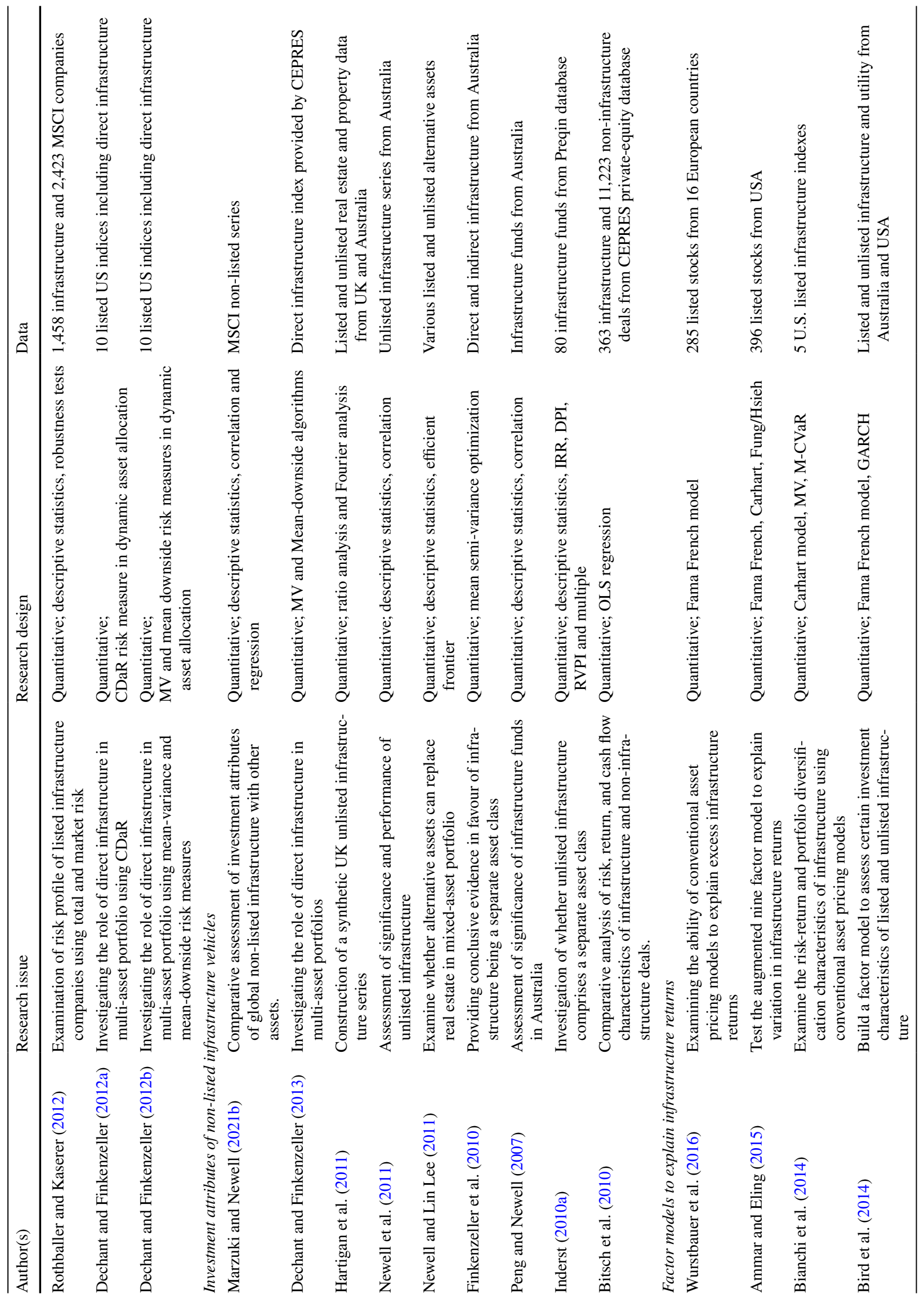




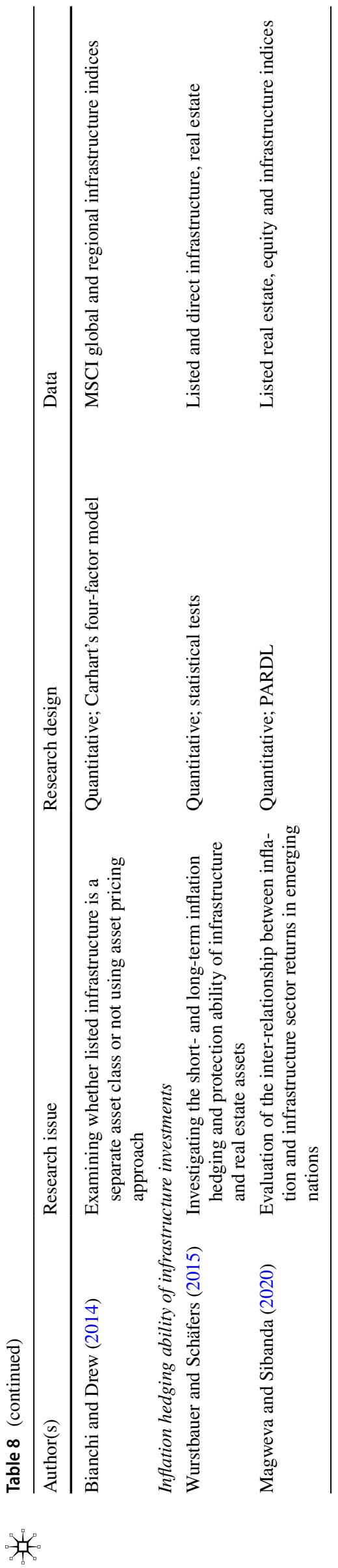

industry make these investments relatively less risky and attractive to investors. While most of the studies investigate economic infrastructure only, Gharaibeh (2019) assesses the performance attributes of six different infrastructure subsectors (including healthcare and education) against stocks and bonds. The author found huge variation in risk-return profiles and validates infrastructure not being an asset class. He also finds strong correlation between infrastructure subsectors and equity but not with bonds. In a multi-asset portfolio, healthcare and education tend to dominate the optimal portfolio selection.

Using composite infrastructure data, Lee (2019) employs a combination of Markowitz model and Monte Carlo simulation to study the variability of investment earnings rate in South Korea and found that the combined model resulted in 23 percent higher earnings rate than the actual earnings rate calculated through Markowitz model alone. The author suggests a lesser than expected earnings rate could be the reason for insufficient investment by institutional investors in South Korean infrastructure and real estate. However, Markowitz model provided more stable earnings based on Sharpe ratios making it suitable for more risk-averse investors. In another interesting study, Rothballer and Kaserer (2012) attempt to assess the risk profile of listed infrastructure companies using both total risk and market risk measures. As opposed to general notion, the authors find presence of comparable total corporate risk as MSCI All Country World index; however, market risk of infrastructure companies was significantly lower than MSCI. The presence of high idiosyncratic risks in infrastructure investments was partially explained by factors including construction risks, exposure to legal changes, high operational risk and lack of product diversification.

Another interesting observation is the region of study. Most of the studies in this cluster cater to more matured markets in terms of privatization of infrastructure assets such as Australia (Reddy 2016), UK (Bond et al. 2007; Oyedele et al. 2014), Europe (Oyedele et al. 2013) and USA (Newell and Peng 2008a; Dechant and Finkenzeller 2012a, 2012b). Oyedele et al. (2014) compare the performance of global listed infrastructure with assets such as stocks, bonds, REITs, direct property, hedge funds and private equity and found a robust risk-adjusted performance. In a multi-asset portfolio, the authors suggest an allocation of $10 \%$ to $17.63 \%$ to listed infrastructure to improve diversification. The authors found that infrastructure acts more as a risk reducer than return enhancer in a multi-asset portfolio. In their seminal work, Blanc-Brude et al. (2017) employ 22 proxies of infrastructure based on three different definitions identified from the literature in a comparative analysis using meanvariance spanning tests. The authors argue that infrastructure based on industry sector classification does not represent a separate asset class and is already spanned by existing 
capital market instruments. Therefore, using listed infrastructure indices as a proxy for privately held infrastructure is completely misguided. Moreover, only 4 out of 22 proxies marginally improved the reference mean-variance portfolio. In a series of studies, Oyedele et al. (2013) and Oyedele et al. (2014) investigate the performance of listed infrastructure in European and UK markets, respectively. Based on a 10-year sample period, both the studies depict similar results and find strong risk-adjusted performance of infrastructure in mixed-asset portfolios even during the downturns. As opposed to this, Bond et al. (2007) find significant improvement in portfolio performance of an institutional investor by adding real estate but not infrastructure. In addition, higher infrastructure returns were coupled with higher volatility. Reddy (2016) analyses whether infrastructure can replace real estate in two-asset and multi-asset portfolios of superannuation funds. With a Sharpe ratio of 0.52 , direct property outperformed all the other asset classes including infrastructure. However, author argues that going forward, allocation to traditional asset classes in pension funds' portfolios is going to shift in favour of direct property and infrastructure. Considering a 6-year timeframe, Newell and Peng (2008a) test the performance of US listed infrastructure in investment portfolios. Authors find evidence of better risk-adjusted returns, reduced risks and improved portfolio diversification. In an attempt to fill an important research gap, Dechant and Finkenzeller (2012a, 2012b) investigate the performance of direct infrastructure in investors' multiasset portfolios using a transaction-based index constructed from 930 operational infrastructure projects in the USA. Using mean-variance, mean downside risk and CDaR-based portfolio optimization algorithms, the authors find that current allocation to infrastructure is clearly sub-optimal and investors who are more concerned with protection of their wealth from downside risk than maximizing returns should consider infrastructure in their asset allocation strategies. Infrastructure is consistently allocated to low and mediumrisk portfolios to an extent of $32 \%$ and $28 \%$, respectively. However, high correlation was found between infrastructure and large cap stocks, limiting its allocation where large cap stocks are already included in investors' portfolios.

While most of the studies are based on either global data or developed markets, we found few studies based on emerging markets' data. Sawant (2010) examines the riskreturn profile of infrastructure project bonds using a dataset of 105 project bonds spanning 15 countries and 5 sectors. While infrastructure project bonds exhibited a better performance during Asian financial crisis and the GFC, the overall risk-return profile was not attractive with negative Sharpe ratio of -0.20 as compared to equity infrastructure indices (MGII is 0.19 , S\&P GII is 0.15 , CSFB EMII is 0.26 , EMBI is 0.18 , GSCI is 0.02 ), and US Treasuries (0.14). Furthermore, infrastructure project bonds were found less capable than syndicated lending mechanisms in mitigating political risks, which is also reflected in their low returns. Two recent studies examine the performance of infrastructure using listed Indian data. While Hasnat (2021) uses a composite Nifty infra index, Majumder (2021) uses eight different Nifty thematic indices including energy and infrastructure. Based on standard CAPM and M-GARCH, Hasnat (2021) finds lower returns and lower volatility for Nifty infra as compared to Nifty 50. Also, the author concludes that the asset class is more prone to exchange rate changes indicating large foreign investment. No evidence of stable and resilient cash flows is found particularly for smaller firms. Majumder (2021) find significant return and volatility spillover effects of infrastructure and energy on other thematic sectors. Another Indian study (Singhal et al. 2011) finds strong risk-adjusted performance of Indian infrastructure relative to global infrastructure, Asia-Pacific infrastructure, global stocks and Indian stocks. The asset class specifically performed strongly when stress tested during the GFC. In an earlier study, Newell et al. (2009) analyse the performance of 25 Chinese listed infrastructure companies and found similar results. However, authors observe some loss of portfolio diversification benefits in later sub-periods.

\section{Review}

Thierie and Moor (2016) adopt a review approach to synthesize the existing literature on risk-return characteristics of infrastructure investments. Authors find a vast heterogeneity across infrastructure sub-sectors, stage of development (greenfield or brownfield investments) and regions. Despite the growing need of infrastructure financing worldwide, little knowledge of its investment characteristics makes investors reluctant to invest in this particular asset class. The study is an attempt to reduce this ambiguity and provide future research prospects.

\section{Investment attributes of non-listed infrastructure vehicles}

There are rather contradictory views on whether listed infrastructure is an appropriate proxy for infrastructure as an asset class or not. In a study by Marzuki and Newell (2021b), performance of a non-listed infrastructure benchmark series given by MSCI is compared with global listed assets, property, bonds and stocks. Over an 11-year period, infrastructure exhibits strong risk-adjusted returns and lower volatility than any other asset class. Moreover, evidence of inflation linked returns and portfolio diversification benefits was also found. Interestingly, four out of seven studies in this category are based on Australian infrastructure data. This is not surprising as it is the only country having a benchmark for non-listed infrastructure, restricting the extension of similar analysis to other parts of the world. Peng and 
Newell (2007) and Newell et al. (2011) assess the risk-return characteristics and significance of non-listed infrastructure in multi-asset portfolios and find strong risk-adjusted returns and portfolio diversification potential over 1995-2009. The asset class depicts robust performance when stress tested during the GFC with some loss of diversification potential in later years. In a similar study, Newell and Lin Lee (2011) observe a diminishing allocation to real estate when other alternative assets are added to a multi-asset portfolio, specifically listed and unlisted infrastructure. The authors also suggest a need for increased allocation to infrastructure (currently $1 \%$ ) by Australian superannuation funds. Using mean semi-variance optimization, Finkenzeller et al. (2010) conclude that infrastructure and real estate deserve separate allocations in institutional investors' portfolios. Although unlisted infrastructure provides improved risk and returns, investors should also account for factors like illiquidity, lack of flexibility and transaction costs. Hartigan et al. (2011) attempt to construct a non-listed infrastructure benchmark series for the UK. Out of 5 different series constructed, the one created through Fourier transformation tested to be the most accurate. The authors suggest target allocations of $80 \%$ and $20 \%$ for unlisted and listed infrastructure, respectively, in investors' balanced portfolios. In a US-based study, the authors use a transaction-based index derived by CEPRES as a proxy for US direct infrastructure to analyse its role in multi-asset portfolio (Dechant and Finkenzeller 2013). The authors also support the better predictability of mean downside risk (MDR) optimization on the premise that investors are more concerned with the safety of their investment than returns. Findings of the study also indicate rising correlation between direct infrastructure and large cap stocks in the long run. In another study, Bitsch et al. (2010) use a private-equity type deal-based dataset to conduct a comparative analysis of risk, return and cash flow characteristics of infrastructure and non-infrastructure deals. The findings of the study are rather mixed and interesting. While authors find evidence of lower downside risk, high correlation to public equity markets, and high returns in infrastructure deals, their findings could not corroborate with the views that infrastructure deals provide stable and inflation-linked cash flows. Inderst (2010a) empirically tests the investment performance of 80 unlisted infrastructure funds sourced from Preqin over 1993-2010. Based on median IRRs, DPI, RVPI and cash flows of the funds, the author concludes that infrastructure is not a separate asset class rather a sub-sector within traditional financing vehicle on which it comes.

\section{Factor models to explain infrastructure returns}

It is well documented in the literature that infrastructure investments provide excess returns than traditional asset classes. However, the identification of factors behind these returns is still an under-researched area. Few studies attempt to explain the variation in infrastructure returns using traditional factor models. Wurstbauer et al. (2016) create an equity dataset of 285 infrastructure sector companies from 16 European countries and analyse whether conventional asset pricing models are able to explain infrastructure returns or not. The authors consider a 'pure play' approach for the selection of companies. The authors augment the Fama French three-factor model with two additional factors, interest rate risk and default risk. However, the model could only explain $52 \%$ of the variation in returns. Regulatory restrictions on infrastructure assets and presence of high idiosyncratic risks could be some of the major reasons for this variation. Ammar and Eling (2015) conduct a similar study in US market with 396 infrastructure companies as their sample size. To test the variation in returns, the authors augment Carhart's four-factor model with five additional factors, i.e. leverage, cash flow volatility, investment growth, default premium and term premium. The nine-factor model exhibited more explanatory power than Fama French threefactor model, Carhart's four-factor model and Fung/Hsieh eight-factor model. To assess the performance of US utilities sector, Bianchi et al. (2014) re-construct the US listed infrastructure index from 1927 to 2010 by mapping its monthly returns to industry and systematic risk factors. Findings suggest that infrastructure cannot be considered a separate asset class, rather it is a subset of broader US stocks' universe. Market risk (beta) and returns of utility sector explained major part of variation in infrastructure returns. The authors argue that most of the infrastructure indexes dominate meanvariance and mean-CVaR portfolios by marginally higher returns and lower tail-risks. In their working paper, Bianchi and Drew (2014) find that infrastructure returns can be significantly explained by world listed stocks and utilities asset classes. The results also show presence of insignificant intercept term highlighting absence of additional risk premium which cannot be mapped by existing stocks. The study provides a conclusive evidence of infrastructure not being a separate asset class. In contrast, Bird et al. (2014) build a robust factor model to capture infrastructure returns employing Australian and US infrastructure and utility dataset and find evidence of excess returns and inflation hedging potential of infrastructure investments, but not of defensive ability.

\section{Inflation hedging ability of infrastructure investments}

Infrastructure assets are considered to provide stable cash flows and inflation linked returns due to their monopolistic/quasi-monopolistic features. However, two studies conducted in this context refute this claim. Magweva and Sibanda (2020) analyse the inflation hedging ability of infrastructure stocks with respect to real estate and general equity in BRICS nations. The study uses a panel data approach 
to find the inability of real estate, infrastructure and equity to sufficiently hedge inflation both in short and long run. Wurstbauer and Schäfers (2015) in another study find that only direct infrastructure depicted some inflation hedging ability in the short run. Results of co-integration tests show that real estate and infrastructure move together with inflation in the long run but are not substitutes of each other.

\section{Discussion and future research prospects for investment performance perspective}

Benchmarking infrastructure investments' performance is another promising area for further advancement of this research field. We find rather contradictory evidence on whether infrastructure exhibits risk-return profile that it promises or is simply a part of traditional investment vehicles on which it comes. While some studies (Peng and Newell 2007; Newell et al. 2011; Oyedele et al. 2013) present evidence of strong risk-adjusted performance and portfolio diversification potential of infrastructure and suggest a separate allocation in institutional investors' portfolios, others (Bond et al. 2007; Blanc-Brude et al. 2017) contradict and argue that listed infrastructure cannot be considered a separate asset class and is rather a subset of general equity. For instance, Dechant and Finkenzeller (2012a, 2012b) could not find evidence of infrastructure being a good hedge against long-term pension liabilities, thus, defying a long held notion. Scholars can further attempt to investigate the role of infrastructure specifically in a liability framework and with longer holding periods? Differences across empirical results could be partially attributed to differences in sample datasets (listed, unlisted), timeframe of analysis (longer, shorter, including or excluding GFC), and rather arbitrary definitions of infrastructure (business model, industry sectors based on codes). Empirical evidence further suggests that infrastructure investments are not substantially explained by traditional asset pricing models like Fama-French and Carhart as they seem to be ridden with high idiosyncratic risks. There is a need to look for additional factors which can better explain these investments and help investors better diversify and benchmark their portfolios. Bitsch et al. (2010) reasonably conclude a significant impact of regulatory environment on the performance of infrastructure deals. However, we did not find any evidence to incorporate this factor in practice. More specifically, how to measure the influence of regulatory and political risks on infrastructure and non-infrastructure deals? how traditional factor models can be augmented with additional factors that can capture the idiosyncratic, asset valuation and liquidity risks inherent in infrastructure investments? which risk-sharing mechanisms can be worked out between private and public sectors to mitigate idiosyncratic risks present in infrastructure investments?
Another interesting observation is that we found only 5 studies under this perspective which focus on the individual sub-sectors of infrastructure. Low correlations, huge variation in returns and volatilities across infrastructure subsectors definitely point towards an inherent heterogeneity in this sector (Thierie and Moor 2016; Gharaibeh 2019). Therefore, we agree with Gharaibeh (2019) that institutional investors must recognize this heterogeneity before including infrastructure in their mixed-asset portfolios. Surprisingly, despite a wider acceptability of inherent heterogeneity in infrastructure, majority of the studies consider it as a composite asset class. One of the potential reasons for this could be the non-availability of sub-indexes representing various sub-sectors like water, energy, utilities, transport, telecommunication and healthcare. Limitation of studies investigating infrastructure sub-sector-wise provides us with potential future research directions. More precisely, what could be the factors explaining the variation in returns and volatilities across infrastructure sub-sectors? can composite infrastructure replace the inclusion of individual sub-sectors in institutional investors' portfolios? Moreover, we agree with the notion of Magweva and Sibanda (2020) that a further promising area could be to assess the resilience of infrastructure returns during different inflation regimes such as hyperinflation, creeping and galloping and with different sub-sectors. It should be carefully noted that monopolistic characteristics vary across different infrastructure sub-sectors to a large extent. For instance, utilities (water, energy) have relatively inelastic demand and therefore, exhibit greater pricing power, whereas telecom and transportation are highly competitive sub-sectors. As a result, inflation hedging ability of different sub-sectors might also differ. Essentially, do regulated utilities hedge inflation better than unregulated sectors? How different sub-sectors perform during different inflation regimes? Another interesting research prospect could lie in the examination of IPO performance of sub-sectors other than seaports. We found only one study to analyse the performance of IPOs in seaports industry. It would be interesting to see how port-related IPOs perform when compared to non-port related IPOs? How institutional variables of host and home countries influence the performance of IPOs in both long and short-run?

Due to data restrictions, majority of the studies examine infrastructure based on listed data only. This can also be seen from the existing literature since almost every study examines the performance of unlisted infrastructure based on Australian index series due to unavailability of similar data for other countries. However, due to vast differences in macroeconomic setup across countries, same index series cannot be used to generalize the results globally. There is ample evidence of unlisted infrastructure performing better than its listed counterpart making it imperative to benchmark unlisted infrastructure in other countries as well. In 
this regard, we find great potential to extend and complement the work of Hartigan et al. (2011). Geographically, most of the empirical work is limited to matured markets of Australia, USA and Europe. Growing economic significance of emerging markets like India and China presents ample opportunities for both domestic and foreign institutional investors to invest in their infrastructure needs. However, more sophisticated empirical work needs to be done to provide a clear picture of infrastructure performance in these markets. Further, as cautioned by Newell et al. (2009), infrastructure markets are less transparent in countries like China, making investors more prone to losses. Therefore, it is advisable for investors to map out risk management and exit strategies before entering such markets.

\section{Policy perspective}

Policy perspective focus on the regulatory side of infrastructure investments. Although infrastructure as an asset class has emerged as a potential investment option for institutional investors, this sector is still ridden with barriers hindering private investment, majority of which are policy-related. Many studies have found regulatory barriers to be one of the dominant reasons for a subdued institutional investment in this sector. We identified 23 studies (Table 9) which focus on the major regulatory barriers and policy recommendations required to boost institutional investment in infrastructure, especially from pension funds.

\section{Barriers and policy recommendations}

Arezki et al. (2017) mention a savings glut worth USD 100 trillion worldwide in pension funds' industry and emphasize the need to channelize these excess low-yield savings to finance deprived, high return infrastructure sector. The authors suggest that instead of treating PPP projects as bilateral contracts between a private party and a government agency, host countries should transform relationships between PPP and multi-lateral development banks (MDBs) facilitating the creation of multilateral guarantee funds. These funds can take on political, construction, regulatory and exchange rate risks and make infrastructure sector more attractive to private institutional investors. Another study identifies advancing current efforts to push institutional investors take equity stakes in infrastructure, development of infrastructure bonds for facilitating refinancing of infrastructure projects, and enhancing the role of governments and MDBs to encourage private finance as three major areas that need to be worked upon in order to develop infrastructure into an asset class (Ketterer and Powell 2018). Vecchi et al. (2017) provide a comprehensive classification and assessment framework for infrastructure investment instruments, their risks and impact at both project and system level to aid policymakers in designing the most suitable instruments at par with investors' expectations. The most common risks identified are political, regulatory, market and technical. The authors suggest policy tools to mitigate these risks such as grants/subsidies, availability-based PPP projects, credit enhancement policies and direct provision of debt and equity capital to distressed projects. In a more recent study, Gabor (2021) discusses the importance of de-risking infrastructure assets by regulatory authorities in order to protect institutional investors from various political and demand risks. The author emphasizes the need to make institutional changes such as credit creation via capital markets, longer intermediation chains, commercial banks with business models that involve complex market-making procedures for securities, derivatives and repo markets, and sophisticated structures of tracing and regulating these markets to attract the savings glut of pension funds and insurance companies. Chicker and Garvin (2009) identify illiquidity, government policies and weaknesses in legal and regulatory framework as some of the major reasons for a hesitant participation by private players in this growth trajectory. Rise of infrastructure funds seems to be a potential solution for bridging infrastructure investment gap provided much-needed policy changes are implemented.

Drawing on the results of a survey conducted by the OECD, Della Croce $(2011,2012)$ categorizes the identified barriers into three major categories-the investment opportunities, the investor capability and the conditions for investment. Due to this, only few funds, majorly larger ones make separate allocation to infrastructure, whereas others invest as part of their equity or fixed income allocation only. In a follow-up study, Della Croce and Yermo (2013) highlight the major trends in long-term financial intermediation focusing on the role of institutional investors in bridging infrastructure investment gap. Some of the major reasons for the under-investment are short-termism pervasive across capital markets, regulatory constraints, lack of financing vehicles, limited investment and risk management expertise, and unavailability of reliable and quality data. The author suggests major policy actions required to address each of these set of barriers for providing a conducive and enabling environment to boost pension funds' investment in infrastructure in developed countries. Since infrastructure is considered to have monopolistic/quasi-monopolistic characteristics, MirrleesBlack (2014) provides an overview of RPI-X adoption across OECD countries and industries. RPI-X mechanism deals with price cap regulations developed in UK and now being adopted worldwide. However, this mechanism should be adopted with flexibility, keeping in mind the vast diversity across regions, as also stated by Littlechild (1983) that 'regulation is just a means to an end and should not be confused with the ultimate outcome'. Page et al. (2008) examine the viability of private equity as an alternative funding source 
Table 9 Policy perspective

\begin{tabular}{|c|c|c|c|}
\hline Author(s) & Research issue & Research design & Data \\
\hline \multicolumn{4}{|c|}{ Barriers and policy recommendations } \\
\hline Gabor (2021) & $\begin{array}{l}\text { De-risking infrastructure projects, markets to boost private } \\
\text { investment }\end{array}$ & Conceptual & n. a \\
\hline Eke et al. (2021) & $\begin{array}{l}\text { Investigate whether prior savings theory holds true in } \\
\text { Nigeria }\end{array}$ & $\begin{array}{l}\text { Quantitative; multivar- } \\
\text { iate statistical tests }\end{array}$ & Macroeconomic variables \\
\hline Savoia et al. (2019) & $\begin{array}{l}\text { Evaluate whether Implied Cost of Capital (ICC) model is } \\
\text { better than CAPM in forecasting realized rate of return }\end{array}$ & $\begin{array}{l}\text { Quantitative; descrip- } \\
\text { tive statistics, ICC } \\
\text { and CAPM }\end{array}$ & $\begin{array}{l}49 \text { listed infrastructure } \\
\text { companies from Brazil }\end{array}$ \\
\hline Gatzert and Kosub (2017) & $\begin{array}{l}\text { Investigate the barriers to infrastructure investment with a } \\
\text { focus on insurance industry }\end{array}$ & Conceptual & n. a \\
\hline Arezki et al. (2017) & $\begin{array}{l}\text { Proposing a solution to transform PPPs into hybrid con- } \\
\text { tractual arrangements }\end{array}$ & Qualitative; descriptive & n. a \\
\hline Vecchi et al. (2017) & $\begin{array}{l}\text { Identification and classification of infrastructure invest- } \\
\text { ment instruments to target various risks }\end{array}$ & Qualitative; descriptive & n. a \\
\hline Mirrlees-Black (2014) & $\begin{array}{l}\text { Provides an overview of the extent to which RPI-X regula- } \\
\text { tions are adopted worldwide }\end{array}$ & Conceptual & n. a \\
\hline Panayiotou and Medda (2014) & $\begin{array}{l}\text { Identification and examination of financial and regulatory } \\
\text { barriers to private investment in UK infrastructure }\end{array}$ & Conceptual & n. a \\
\hline Datz (2013) & $\begin{array}{l}\text { Discussing the growing role of pension funds in economic } \\
\text { growth of Brazil }\end{array}$ & Conceptual & n. a \\
\hline Little (2010) & $\begin{array}{l}\text { Providing a potential solution to US infrastructure prob- } \\
\text { lems via pension funds' investment }\end{array}$ & Conceptual & n. a \\
\hline Chicker and Garvin (2009) & $\begin{array}{l}\text { Investigation of barriers hindering the growth of infra- } \\
\text { structure investment }\end{array}$ & Conceptual & n. a \\
\hline Page et al. (2008) & $\begin{array}{l}\text { Examining the viability of private equity funds in making } \\
\text { infrastructure investments }\end{array}$ & Conceptual & n. a \\
\hline Orski (2008) & $\begin{array}{l}\text { Complementing highway tolls with private equity to } \\
\text { finance infrastructure in USA }\end{array}$ & Conceptual & n. a \\
\hline Clark and Root (1999) & $\begin{array}{l}\text { Understanding the advent and role of Private Finance } \\
\text { Initiative (PFI) in UK infrastructural development }\end{array}$ & Conceptual & n. a \\
\hline Ketterer and Powell (2018) & $\begin{array}{l}\text { Identifying measures to develop infrastructure into an asset } \\
\text { class }\end{array}$ & Qualitative; descriptive & n. a \\
\hline Oberholzer et al. (2018) & Overview of infrastructure as an asset class in Africa & Qualitative; descriptive & n. a \\
\hline Inderst (2016) & $\begin{array}{l}\text { Overview of infrastructure financing and investment in } \\
\text { Asia }\end{array}$ & Qualitative; descriptive & n. a \\
\hline Inderst and Stewart (2014b) & $\begin{array}{l}\text { Evaluation of potential of institutional investors to bridge } \\
\text { infrastructure investment gap in Emerging Market and } \\
\text { Developing Economies (EMDEs) }\end{array}$ & Qualitative; descriptive & n. a \\
\hline Della Croce and Yermo (2013) & $\begin{array}{l}\text { Overview of major trends in long-term financial interme- } \\
\text { diation with a special focus on the role of institutional } \\
\text { investors in infrastructure financing }\end{array}$ & Qualitative; descriptive & n. a \\
\hline Inderst (2009) & $\begin{array}{l}\text { Overview of state of pension funds' investment in infra- } \\
\text { structure, barriers and potential solutions }\end{array}$ & Qualitative; descriptive & n. a \\
\hline Della Croce (2011) & $\begin{array}{l}\text { Suggest policy actions to tackle barriers to pension fund } \\
\text { investment in infrastructure }\end{array}$ & Qualitative; descriptive & n. a \\
\hline Della Croce (2012) & $\begin{array}{l}\text { Drawing on the OECD survey results specifically catering } \\
\text { to pension funds' investments in infrastructure }\end{array}$ & Qualitative; Survey & 28 largest pension funds \\
\hline Ehlers (2014) & $\begin{array}{l}\text { Studying main challenges to private investment in infra- } \\
\text { structure }\end{array}$ & Qualitative; descriptive & n. a \\
\hline
\end{tabular}

to curb US infrastructure deficit. The authors illustrate that tolls and other user fees combined with private equity investment funds (PEIF) can prove to be a useful funding source if policymakers address certain requirements of PEIFs such as shorter durations and re-financing issues. Further, Orski (2008) also suggests a mix of revenues generated from highway tolls and private equity to cover the transportation infrastructure deficit in the USA without burdening the 
taxpayers. As it is well known, large infrastructure projects are predominantly financed through debt which makes them even more vulnerable. To cater this, Little (2010) emphasizes the establishment of a US National Infrastructure Bank (NIB) for fulfilling debt requirements of institutional investors. It has been stressed on many occasions that assessment of qualitative factors should complement quantitative analysis while benchmarking complex infrastructure investments. We found many publications catering to the European market, for instance, Clark and Root (1999) examine the viability of private finance initiative (PFI) taken by UK government to make up for the shortfall in infrastructure investment. They argue that the formal mechanism of PFI is foundered upon inherently flawed design and bureaucrats' obsession with control of public spending. It can only succeed if the mechanism is decentralized and linked with regional development programmes. Panayiotou and Medda (2014) list various financial and regulatory challenges in private infrastructure investment in the UK. The authors highlight that inadequate and inappropriate benchmarking of greenfield infrastructure projects often redirects investors to less-risky brownfield investments. Introduction of a 'split-finance model' can address the needs of investors and banks along different phases of a project, specifically in case of greenfield projects. Further, authors suggest setting up a sovereign wealth fund in UK to boost investors' confidence and mitigate political risks. Similarly, the European initiatives which are intended to overcome the challenges faced by insurance companies while investing in infrastructure are dwarfed by various project-specific risks, specifically regulatory restrictions and inadequate data transparency including lack of suitable investment vehicles as major obstacles to invest (Gatzert and Kosub 2017). Various initiatives taken by government such as project bond initiative (PBI) and Investment plan for Europe (EFSI) can contribute to increased transparency and availability of suitable investment vehicles. Increased credit ratings can also promote investor confidence and reduce solvency capital requirements (SCR) for insurance industry.

A thorough evaluation of the findings of a survey conducted by the World Bank reveal lack of viable projects, restrictive political environment, investment restrictions, and capital markets under-development as some of the major barriers to adequate institutional investment in EMDE (Emerging Markets and Developing Economies) infrastructure. Additionally, the study emphasizes the need to create an enabling environment to meet the specific needs of institutional investors via some combination of legal/ regulatory reform, capacity building, credit enhancement/ intermediaries and project restructuring (Inderst 2009; Inderst and Stewart 2014b). Continuing this, Inderst (2016) investigates the state of infrastructure financing and investment in Asia from a global perspective. The author finds that bank loans still play a major role in financing infrastructure in Asia with marginal contribution from private sector. Investor regulation acts as one of the major barriers to private participation in Asian infrastructure. Many policy changes including easing investor regulations, deepening the capital markets, streamlining the role of public sector loans for infrastructure and establishment of facilitating intermediaries like infrastructure banks are recommended to bring institutional investment at par with global levels. Ehlers (2014) identifies lack of investable projects as the biggest challenge in channelizing long term finance to infrastructure investments in emerging markets. Complementing traditional sources of finance like bank loans and direct equity investments, bond markets and infrastructure funds exhibit great potential in this regard. Policymakers need to extend their attention towards developing capital markets, reliable legal networks and a long-term investor base for boosting infrastructure investment. Similarly, Oberholzer et al. (2018) find limited number of financial instruments and funds, a preference for traditional asset classes and a lack of expertise in analysing infrastructure projects, a limited number of available investable infrastructure projects, a mismatch between available projects and requirements, and regulatory thresholds for infrastructure investments as five major reasons for a hesitant infrastructure investment in Africa from institutional investors despite having huge potential. Eke et al. (2021) test whether prior savings theory holds true in case of Nigerian pension fund industry and find evidence that pension funds' savings do not flow towards infrastructure development, rather is spent on consumption expenditure which can be harmful for a developing nation like Nigeria. We found two studies to focus on the Brazilian market. Datz (2013) highlights the growing significance of pension funds as suppliers of infrastructure finance calling it 'pension fund developmentalism'. Becoming the most active class of investors, pension funds are poised to push for legal and economic changes to lower risks in long-term infrastructure investments in Brazil. Savoia et al. (2019) use purposive sampling to select 49 listed infrastructure companies of Brazil and investigate which capital cost model, i.e. implied cost of capital (ICC) or capital asset pricing model (CAPM) is better in predicting the realized rate of return of selected infrastructure firms. Interestingly, the authors find that cost of equity calculated through CAPM is lower by $1.42 \%$ than ICC indicating a lower estimation of cost of equity by the government as one of the reasons to discourage institutional investors from investing in infrastructure. This sufficiently concludes that growth of pension funds in Brazil is contingent upon government's continuous efforts in maintaining inflation targets and implementing structural reforms. However, insurance companies and pension funds should carefully evaluate these investments as some project risks still remain. 


\section{Discussion and future research prospects for policy perspective}

Studies categorized under this perspective address regulatory and political risks as major barriers in scaling up infrastructure investments across the globe. While majority of the studies suggest policy and institutional changes, it is easier said than done. More precisely, how can investors incorporate regulatory risk premium while benchmarking infrastructure investments? What impact do regulatory barriers have on the infrastructure investments of emerging markets? Moreover, we find only one study (Arezki et al. 2017) to explicitly investigate the role of MDBs in promoting private sector participation. Surprisingly, no implications in this regard are being presented. Scholars can investigate what role do MDBs play in facilitating institutional investment for infrastructure development? Another limitation associated with the study of Savoia et al. (2019) is sourcing a smaller sample size which restricts the wider applicability of the analysis. Scholars can extend the analysis with increased sample size and to other parts of the world. More precisely, which method between ICC and CAPM is being used in other countries to calculate realized investment returns? Can the analysis be replicated to other emerging markets having similar investment environment as Brazil? Especially in the context of EMDEs, there is a need to create a framework which can assess which investment vehicles will suit the best for what kind of conditions and regions? Vecchi et al. (2017) suggest five policy measures to boost institutional investment in infrastructure. Though it is imperative to adopt these measures, testing the impact of these measures post adoption becomes even more prominent. More specifically, do policy measures significantly help in scaling up infrastructure investments? However, the amendments and policy changes suggested in the sample contributions get implemented over time only. To get the much-needed support of private sector in near future, governments need to step up and act as a facilitator to take care of investors' needs.

Many studies show confidence in the potential of pension funds to bridge the infrastructure investment gap. Researchers provide a target allocation of at least $5 \%$ to infrastructure in the portfolios of institutional investors, but reality is grim. Despite having a competitive advantage, pension funds are allocating only around $1 \%$ of their assets to infrastructure. This might be due to low confidence of pension funds in this industry and various constraints concerning the inter-relationships among pension funds, regulatory bodies and multilateral agencies. We encourage scholars to deeply investigate the viability of other funding options for scaling up institutional investment in infrastructure. More precisely, how prominent a role can insurance industry play in infrastructure investments? Can other financing options like private equity and infrastructure bonds prove to be viable for complex infrastructure assets?

\section{Stakeholder perspective}

Infrastructure projects are complex in nature due to involvement of various stakeholders such as regulatory authorities, investors and society at large. This perspective caters to publications which focus on two such stakeholders-investors and society. We have grouped 20 papers (Table 10) under this perspective, out of which 12 cater to investors' aspect and 8 cater to society's aspect. Infrastructure is also unique in the sense that it cannot be treated as a completely commercialized sector due to its importance in provision of basic services. As it is continuously moving towards being an asset class, it is imperative to understand the implications of this change.

\section{Investors' aspect}

This sub-theme deals with the institutional investors' point of view while investing in infrastructure. In some of the earliest studies, Clark (1997) examines the reasons why pension funds are conservative in investing into alternate investment products (AIP), more specifically infrastructure despite having clear competitive edge and high yields. The author identifies two interrelated problems in this regard (1) costs of information asymmetry and (2) the handling of agent (fund trustees) - agent (investment managers) relationship. The solution lies in the extent of ability of financial intermediaries to design the relatively opaque AIPs to mirror the known characteristics of more transparent equity and fixed income traded products making it easier for pension funds to trust such AIPs and increase the level of funding in them. In another study, Clark (1998) attempts to understand why convention dominates the decision making of pension fund trustees? Using case studies and interviews, the author proposes a framework to understand the dominance of convention and concludes that a trio of habits, norms and rules play a significant role in trustee decision making. Similarly, Clark and Evans (1998) examine the state of play of pension funds' investments into urban infrastructure projects. The authors argue that to reap the benefits of private investment into urban infrastructure, mandatory creation of financial intermediaries which are capable of governing long-term contractual relationships between facility managers and investors are required. Orr and Kennedy (2008) provide an overview of recent trends in global infrastructure investment climate. The study focuses on various aspects such as changing role of traditional multilateral agencies, scaling up of local currency investments in emerging markets, financial innovation and engineering of investment vehicles and growing involvement of private sector. 
Table 10 Stakeholder perspective

\begin{tabular}{|c|c|c|c|}
\hline Author(s) & Research issue & Research design & Data \\
\hline \multicolumn{4}{|l|}{ Investors' aspect } \\
\hline Kupperman and Kilgallen (2015) & $\begin{array}{l}\text { Overview of liquid alternatives mar- } \\
\text { ket to be included in DC pension } \\
\text { funds' portfolios }\end{array}$ & Conceptual & n. a \\
\hline Siemiatycki (2015) & $\begin{array}{l}\text { Examining the opportunities and } \\
\text { challenges faced by Canadian } \\
\text { pension funds while investing in } \\
\text { transport infrastructure }\end{array}$ & $\begin{array}{l}\text { Qualitative; in-depth interviews, } \\
\text { case study }\end{array}$ & 7 largest pension funds \\
\hline Jones (2015) & $\begin{array}{l}\text { Understanding how institutional } \\
\text { investors perceive barriers into } \\
\text { clean energy infrastructure and } \\
\text { policy solutions }\end{array}$ & $\begin{array}{l}\text { Qualitative; literature review, Delphi } \\
\text { method }\end{array}$ & n. a \\
\hline Gatzert and Kosub (2016) & $\begin{array}{l}\text { Investigating infrastructure invest- } \\
\text { ment challenges from insurers' } \\
\text { point of view under Solvency II } \\
\text { norms }\end{array}$ & Qualitative; descriptive & n. a \\
\hline Clark et al. (2012) & $\begin{array}{l}\text { Provide insights into how institu- } \\
\text { tional investors can overcome } \\
\text { challenges while investing directly } \\
\text { into infrastructure }\end{array}$ & Conceptual & n. a \\
\hline Inderst (2010b) & $\begin{array}{l}\text { Investigation into pension funds' } \\
\text { claim of infrastructure being a } \\
\text { separate asset class }\end{array}$ & Conceptual & n. a \\
\hline Orr and Kennedy (2008) & $\begin{array}{l}\text { Highlights recent trends in changing } \\
\text { investment patterns globally }\end{array}$ & Conceptual & n. a \\
\hline Newell and Peng (2008b) & $\begin{array}{l}\text { Assessment of motivation and risk } \\
\text { factors for infrastructure fund } \\
\text { managers }\end{array}$ & Qualitative; expert survey & 10 expert responses \\
\hline Clark and Evans (1998) & $\begin{array}{l}\text { Assessment of pension funds invest- } \\
\text { ment in urban infrastructure }\end{array}$ & Conceptual & n. a \\
\hline Clark (1998) & $\begin{array}{l}\text { Proposes a framework to understand } \\
\text { why convention dominates pension } \\
\text { funds' decision-making }\end{array}$ & Qualitative; interview, case studies & n. $\mathrm{a}$ \\
\hline Andonov et al. (2018) & $\begin{array}{l}\text { Examination of infrastructure as an } \\
\text { asset class as available particularly } \\
\text { to pension funds }\end{array}$ & Quantitative; descriptive statistics & n. $\mathrm{a}$ \\
\hline Clark (1997) & $\begin{array}{l}\text { Assessment of pension conservatism } \\
\text { towards alternative investment } \\
\text { products (AIPs) }\end{array}$ & Qualitative; survey-based & n. $\mathrm{a}$ \\
\hline \multicolumn{4}{|l|}{ Society's aspect } \\
\hline Henn et al. (2016) & $\begin{array}{l}\text { Proposes a multi-criteria appraisal } \\
\text { framework to assess alternative } \\
\text { financing approaches }\end{array}$ & Qualitative; MCA and CBA & n. a \\
\hline O’Neill (2017) & $\begin{array}{l}\text { Examining the implications of pri- } \\
\text { vate sector financing for Australian } \\
\text { urban infrastructure }\end{array}$ & Conceptual & n. a \\
\hline Torrance (2009a) & $\begin{array}{l}\text { Implications of growing pension } \\
\text { funds' investment for urban land- } \\
\text { scape }\end{array}$ & Qualitative; interview-based study & 40 interviews with key players \\
\hline Torrance (2009b) & $\begin{array}{l}\text { Investigation of growing role of } \\
\text { pension funds in infrastructure } \\
\text { landscape across geographies }\end{array}$ & Qualitative; interview-based study & 40 interviews with key players \\
\hline Whiteside (2017) & $\begin{array}{l}\text { Analysis of Canada Infrastructure } \\
\text { Bank (CIB) infrastructure develop- } \\
\text { ment practices }\end{array}$ & Conceptual & n. a \\
\hline
\end{tabular}


Table 10 (continued)

\begin{tabular}{|c|c|c|c|}
\hline Author(s) & Research issue & Research design & Data \\
\hline Tricarico and Sol (2016) & $\begin{array}{l}\text { Identification of risks and challenges } \\
\text { of new mega wave of infrastructure } \\
\text { assets }\end{array}$ & Qualitative; descriptive & n. a \\
\hline Clayton et al. (2007) & $\begin{array}{l}\text { Exploring the changing patterns in } \\
\text { real estate markets as it comes of } \\
\text { age }\end{array}$ & Conceptual & n. a \\
\hline Sharma (2012) & $\begin{array}{l}\text { Investigates how the wider social and } \\
\text { economic benefits are impacted by } \\
\text { a shift in ownership and financing } \\
\text { in infrastructure sector from public } \\
\text { to private sector }\end{array}$ & Qualitative; case study & $\begin{array}{l}\text { Auckland International Airport } \\
\text { Limited; ADI takeover of } \\
\text { BAA }\end{array}$ \\
\hline
\end{tabular}

Some of the more recent studies seek to understand how pension funds have evolved to be the most suitable among institutional investors for infrastructure investments. Kupperman and Kilgallen (2015) draw on the experience of defined benefit pension plans (DB) and propound the inclusion of alternative assets in the portfolios of defined contribution (DC) plans as well for improved risk-return profile. Although majority of studies in this category cater to composite infrastructure, Siemiatycki (2015) investigates opportunities and challenges for Canadian pension funds in delivery, financing and operation of transportation infrastructure. The author collects evidence from seven largest pension funds in Canada and concludes that few types of assets, geographies and deal structures are more likely to attract investments than others. For instance, the largest funds prefer infrastructure assets which are either privately owned or are brownfield over government-initiated PPP projects and greenfield assets. Using a qualitative approach, Andonov et al. (2018) examines infrastructure as an asset class as available to pension funds in the US. The study found statistically significant underperformance by US public pension funds as compared to other private institutional investors while making infrastructure investments through closed-end private-equity type funds. Their underperformance creates an implicit subsidy for either taxpayers who will contribute more to compensate for the underfunding of funds or for pensioners who will receive pension cuts or both. Jones (2015) adopts the Delphi technique and conduct eight semi-structured interviews to identify perceived barriers by institutional investors to restrict investment in clean energy infrastructure. Domestic policy, domestic market, general financial, clean energy specific and physical risks are perceived as major barriers by institutional investors. The author suggests that a long term stable public policy is the foremost requirement to overcome these barriers. Newell and Peng (2008b) also adopt a qualitative survey method to assess the significance of various motivating and risk factors for infrastructure fund managers in Australian infrastructure industry. In total, the authors identify 13 motivating and 15 risk factors. Out of these, liability matching and long duration, predictable and stable cash flows and a greater understanding of inherent risks were found to be the most influential motivating factors, whereas uncertain political environment, over-valuation of infrastructure assets and lack of investible assets were the prominent risk factors. Addressing insurers' viewpoint, Gatzert and Kosub (2016) highlight the significance of a complete qualitative assessment of various non-quantifiable factors such as political, technological and regulatory along with adequate estimation of solvency capital requirements (SCR) under Solvency II norms. Clark et al. (2012) study the inherent challenges of investing directly in infrastructure assets. While adopting a third-party management model, sponsors have to deal with principal-agent and time inconsistency problems. The authors suggest building of in-house management teams provided the structure of process, people and politics is handled efficiently. Inderst (2010b) argues that the existing research (both qualitative and quantitative) in this field is not sufficient to establish infrastructure as a separate asset class. It may very well be a separate investment vehicle or a subset of the larger securities market universe. However, more granular data on individual investor level is required to better address the barriers to necessary investment. The much of the research provides contradictory results owing to short history, lack of quality data and different methodologies applied by researchers.

\section{Society's aspect}

A deeper understanding of implications of private participation in infrastructure investments helps policymakers make cautious and well-informed decisions before blindly inviting private players to such an imperative sector. O'Neill (2017) adopts a prudent view and examines the impact of private investment on the functioning of Australian urban infrastructure 1980 onwards. Since urban infrastructure provision is now dominated by private players, the questions of social justice, business efficiency and dynamic efficiency 
need addressing. This shift from public-owned utilities structure to private provision focuses more on restructuring the infrastructure assets as per private investors' needs undermining the vested interests of society at large. Torrance (2009a, 2009b) carried out interviews of 40 key players in the global infrastructure market to understand the changing governance and ownership patterns of urban infrastructure in which pension plans have a key role. Institutional investors invest in portfolio of infrastructure assets across geographies to spread risks and generate stable returns. To them, infrastructure assets are not defined on the basis of their physical features, rather investment characteristics. Moreover, pension savings glut and policymakers' decision to do away with infrastructure provision has fuelled the private investment in infrastructure having implications for urban communities. Whiteside (2017) argues that establishment of Canada Infrastructure Bank (CIB) is another deceptive way to long-standing practices of fiscal austerity and privatization measures. The author cautions that CIB is not a real alternative to fund infrastructure development, rather just a way to privatize the existing public assets for the benefit of profit leeching private investors. Instead, society favouring alternatives such as direct public borrowing through bond markets and looking into ways to increase government revenues should be adopted for infrastructure provision in Canada. Providing a comprehensive view, Henn et al. (2016) propose a multi-criteria appraisal framework to assess the effectiveness of various financing approaches. The authors adopt two popular appraisal methods: multi-criteria analysis (MCA) and cost benefit analysis (CBA) to propose a framework based on monetary (economic) factors and intangible (societal) factors comprising six and seven factors, respectively. Based on this framework, the authors conclude that infrastructure bonds are the most effective financing option followed by reserves and external equity. Tricarico and Sol (2016) illustrate the global agenda of turning infrastructure into an asset class as more of a huge Marshall plan to revive global trade and investments. This global agenda of building mega infrastructure projects deems to benefit only $1 \%$ of investors at the huge costs of local communities and environmental degradation. The authors suggest that there is a need for social activists to step up and get ready to confront the challenges coming with the financialization of infrastructure assets. Another important aspect to look for is the growing integration of infrastructure with the global capital markets. Being a part of alternatives' universe, as infrastructure comes of age and gains popularity as a separate asset class, it can become more vulnerable to credit and liquidity risks as in the case of real estate (Clayton et al. 2007). These investment-related risks can, in turn, negatively impact the physical provision of basic infrastructure. However, it is to also note that under the right regulatory and governance conditions, private involvement into infrastructure financing can lead to increased economic activity, improved service quality, reduced public spending and better channelization of private savings. Using two contrasting case studies of privately owned airport projects in Auckland and UK, Sharma (2012) highlights stakeholders' interests, government support and effective administration as important considerations before bringing private sector on board into such an imperative sector as infrastructure.

\section{Discussion and future research prospects for societal perspective}

Stakeholder perspective deals with studies that address the infrastructure as an asset class from investors' and society's point of view. This gives rise to significant potential research avenues, for instance, in the study of Adonov et al. (2018), there was empirical evidence of an underperformance by US pension funds when compared with other private institutional investors. This has huge implications for pension funds if they consider investing further in infrastructure. Therefore, it is imperative to know what could be the factors responsible for the underperformance of public pension funds despite having similar pay out profiles as traditional private-equity funds? It becomes even more prominent in emerging markets with a highly unstable policy environment, inflexible regulatory norms and under-developed capital markets. In the study of Newell and Peng (2008b), preference for motivating factors over risk factors reflects investors' confidence in this particular asset class. However, since the history of infrastructure financing research is relatively short and fragmented, we agree with the notion of Inderst (2010b) that it is still an under-researched area and a lot is yet to be done. More specifically, scholars need to carefully address: Is infrastructure actually a separate asset class or just a range of new investment vehicles? What factors need to be addressed to better capture the risk premium and heterogeneity of infrastructure sector? Have the promises made concerning the contribution of pension funds actually materialized? To ensure proper channelization of pension funds savings to infrastructure projects, continuous policy reforms, financial innovation and improved investor capabilities are required for mutually beneficial relationships.

We find very few studies to address the societal and environmental impact of private participation in infrastructure financing. Although countries around the world are struggling with infrastructure deficit, it is also important to have a cautious view while inviting private players in this sector. Infrastructure sector has huge implications for society and it cannot be simply converted into a commodity so that more privileged can get more of it. We encourage scholars to explore this aspect of infrastructure financing in more detail. Specifically, which infrastructure sub-sectors are 
more prominent from society's point of view and why? How can societal factors be accommodated to benchmark infrastructure investments' performance? Which models concerning public and private involvement in infrastructure provision can be adopted to mitigate negative impacts on society, and environment? Which alternative financing approaches are better suited for community good? Going forward, clean and renewable energy is the need of the hour, however, we found only one study (Jones 2015) focusing on this subsector. More specifically, what are the barriers restricting institutional investment in other prominent sub-sectors like education, healthcare? Given the right regulatory and governance conditions, negative impact of privatization of infrastructure assets can be mitigated and lead to improved economic activity and better infrastructural facilities.

\section{Conclusion and limitations of the study}

The steady growth and ongoing academic discussion reflect the rising eminence, institutionalization and legitimization of infrastructure financing as a research area. As the literature evolves, more important questions concerning infrastructure as an asset class arise that need attention. The purpose of this study is to provide a comprehensive and holistic view of the existing research concerning infrastructure as an asset class and critically evaluate the present evidence.

We compile a dataset of 89 scientific contributions and adopt a hybrid approach combining systematic literature review and detailed thematic analysis to examine them. We classify the dataset into four major perspectives-capital market, investment performance, policy and stakeholder. Research in the past two decades has contributed significantly to this area. Existing body of knowledge highlights the role of various stakeholders including governments, international agencies, non-banking finance companies and institutional investors in the development of infrastructure as an asset class. The present study suggests several future research directions under each perspective (Table 11). With this review, we take a step further towards the advancement of this research area and also provide a base for guiding and encouraging the future research attempts. To the best of our knowledge, this is the first systematic literature review to study infrastructure in an asset class context. Though the list of potential research avenues is not exhaustive, still it provides some interesting and niche areas that need researchers' attention. With the rising popularity of market-based approaches as alternatives to finance infrastructure, it would be interesting to see how these approaches would perform when applied to real world infrastructure projects. Since infrastructure financing is the first stage in building an infrastructure project, there is also a need to analyse the postfunding performance of that particular infrastructure project. For the success of infrastructure financing approaches in the long run, future studies need to investigate the outcome of these approaches and what are the determinants for the success of some specific financing approaches over others. In addition, for market-based financing alternatives to work, examination of their benefits over traditional ones will grab more researchers' attention. In particular, well-functioning capital markets and a stable investment environment are highly relevant for market-based financing to work. Due to the vast heterogeneity among infrastructure sub-sectors, there is a need to carefully analyse which financing approach works best for which sub-sector.

Despite attempting to provide a complete overview of existing literature, the present study is not without its limitations. We only include journal articles and conference papers in our study; however, we observe that a lot of grey literature including industry reports, position and working papers are available in this area which may provide more meaningful insights. Furthermore, we follow a pre-defined inclusion and exclusion criteria in which we include publications only in English language. Although we rely on the collective judgement of both the authors, the subjectivity cannot be entirely removed. We also recognize that themes identified are neither final nor constant and motivate scholars to extend the scope of review presented here. We are just starting to see the changing dynamics and impact of infrastructure financing approaches on various stakeholders involved in infrastructure development. A whole lot of work still needs to be done to understand this impact and underpin the common foundation of infrastructure as an asset class. We are hopeful that our attempt will serve as a foundation to where we are and where we need to go to support further multi-disciplinary research in this field. 
Table 11 Future infrastructure financing research avenues

\begin{tabular}{|c|c|}
\hline Perspective & Possible future research prospects \\
\hline Capital market & $\begin{array}{l}\text { How to assess the financial performance of projects funded through asset-backed securitization? } \\
\text { What factors influence investors to invest in project-backed securities? } \\
\text { How emerging markets could benefit from their relatively resilient capital market in raising much-needed infrastruc- } \\
\text { ture finance? }\end{array}$ \\
\hline Investment performance & $\begin{array}{l}\text { What is the role of infrastructure specifically in a liability framework and with longer holding periods? } \\
\text { How to measure the influence of regulatory and political risks on infrastructure and non-infrastructure deals? } \\
\text { How traditional factor models can be augmented with additional factors that can capture the idiosyncratic, asset valua- } \\
\text { tion and liquidity risks inherent in infrastructure investments? } \\
\text { Which risk-sharing mechanisms can be worked out between private and public sectors to mitigate idiosyncratic risks } \\
\text { present in infrastructure investments? } \\
\text { What could be the factors explaining the variation in returns and volatilities across infrastructure sub-sectors? } \\
\text { Can composite infrastructure replace the inclusion of individual sub-sectors in institutional investors' portfolios? } \\
\text { Do regulated utilities hedge inflation better than unregulated sectors? } \\
\text { How different sub-sectors perform during different inflation regimes? } \\
\text { How port-related IPOs perform when compared to non-port related IPOs? } \\
\text { How institutional variables of host and home countries influence the performance of IPOs in both long and short-run? }\end{array}$ \\
\hline Policy & $\begin{array}{l}\text { How can investors incorporate regulatory risk premium while benchmarking infrastructure investments? } \\
\text { What impact do regulatory barriers have on the infrastructure investments of emerging markets? } \\
\text { What role do MDBs play in facilitating institutional investment for infrastructure development? } \\
\text { Which method between ICC and CAPM is being used in other countries to calculate realized investment returns? } \\
\text { Can the analysis be replicated to other emerging markets having similar investment environment as Brazil? } \\
\text { Which investment vehicles will suit the best for what kind of conditions and regions? } \\
\text { Do policy measures significantly help in scaling up infrastructure investments? } \\
\text { How prominent a role can insurance industry play in infrastructure investments? } \\
\text { Can other financing options like private equity and infrastructure bonds prove to be viable for complex infrastructure } \\
\text { assets }\end{array}$ \\
\hline Stakeholder & $\begin{array}{l}\text { What could be the factors responsible for the underperformance of public pension funds despite having similar pay out } \\
\text { profiles as traditional private-equity funds? } \\
\text { Is infrastructure actually a separate asset class or just a range of new investment vehicles? } \\
\text { What factors need to be addressed to better capture the risk premium and heterogeneity of infrastructure sector? } \\
\text { Have the promises made concerning the contribution of pension funds actually materialized? } \\
\text { Which infrastructure sub-sectors are more prominent from society's point of view and why? } \\
\text { How can societal factors be accommodated to benchmark infrastructure investments' performance? } \\
\text { Which models concerning public and private involvement in infrastructure provision can be adopted to mitigate nega- } \\
\text { tive impacts on society, and environment? } \\
\text { Which alternative financing approaches are better suited for community good? } \\
\text { what are the barriers restricting institutional investment in other prominent sub-sectors like education, healthcare? }\end{array}$ \\
\hline
\end{tabular}

\section{References}

Ammar, S.B., and M. Eling. 2015. Common risk factors of infrastructure investments. Energy Economics 49: 257-273. https://doi. org/10.1016/j.eneco.2015.01.021.

Andonov, A., R. Kräussl, and J. Rauh. 2018. The subsidy to infrastructure as an asset class. National Bureau of Economic Research Paper No. w25045.

Arezki, R., P. Bolton, S. Peters, F. Samama, and J. Stiglitz. 2017. From global savings glut to financing infrastructure. Economic Policy 32 (90): 221-261. https://doi.org/10.1093/epolic/eix005.

Balatbat, M.C., C.Y. Lin, and D.G. Carmichael. 2010. Comparative performance of publicly listed construction companies:
Australian evidence. Construction Management and Economics 28 (9): 919-932. https://doi.org/10.1080/01446193.2010.501805.

Bianchi, R.J., G. Bornholt, M.E. Drew, and M.F. Howard. 2014. Longterm US infrastructure returns and portfolio selection. Journal of Banking \& Finance 42: 314-325. https://doi.org/10.1016/j. jbankfin.2014.01.034.

Bianchi, R. J., and M. E. Drew. 2014. Is infrastructure an asset class? An asset pricing approach. Working Paper.

Bird, R., H. Liem, and S. Thorp. 2014. Infrastructure: Real assets and real returns. European Financial Management 20 (4): 802-824. https://doi.org/10.1111/j.1468-036X.2012.00650.x.

Bitsch, F., A. Buchner, and C. Kaserer. 2010. Risk, return and cash flow characteristics of infrastructure fund investments. EIB Papers 15 (1): 106-136. 
Blanc-Brude, F., T. Whittaker, and S. Wilde. 2017. Searching for a listed infrastructure asset class using mean-variance spanning. Financial Markets and Portfolio Management 31 (2): 137-179. https://doi.org/10.1007/s11408-017-0286-z.

Bond, S.A., S. Hwang, P. Mitchell, and S.E. Satchell. 2007. Will private equity and hedge funds replace real estate in mixed-asset portfolios?. The Journal of Portfolio Management 33 (5): 74-84. https://doi.org/10.3905/jpm.2007.698908.

Braun, V., and V. Clarke. 2006. Using thematic analysis in psychology. Qualitative Research in Psychology 3 (2): 77-101. https://doi. org/10.1191/1478088706qp063oa.

Castro e Silva Neto de, D., C.O. Cruz, F. Rodrigues, and P. Silva. 2016. Bibliometric analysis of PPP and PFI literature: Overview of 25 years of research. Journal of Construction Engineering and Management 142 (10): 06016002. https://doi.org/10.1061/ (ASCE)CO.1943-7862.0001163.

Çelik, S., and M. Isaksson. 2013. Institutional investors as owners: Who are they and what do they do? OECD Corporate Governance Working Papers, No. 11, OECD Publishing, Paris. https:// doi.org/10.1787/5k3v1dvmfk42-en.

Chakkalakal, L., U. Hommel, and W. Li. 2018. Transport infrastructure equities in mixed-asset portfolios: estimating risk with a Garch-Copula CVaR model. Journal of Property Research 35 (2): 117-138. https://doi.org/10.1080/09599916.2018.1461126.

Chen, A.H. 2002. A new perspective on infrastructure financing in Asia. Pacific-Basin Finance Journal 10 (3): 227-242. https:// doi.org/10.1016/S0927-538X(02)00045-8.

Chen, A.H., and J.W. Kubik. 2007. Complementing economic advances in India: A new approach to financing infrastructure projects. The Journal of Structured Finance 13 (2): 29-39. https://doi.org/10. 3905/jsf.2007.690264.

Chicker, G., and M. J. Garvin. 2009. Private equity: growing investment vehicle in infrastructure (No. 1429-2016-118654). In Proceedings of the 50th Annual Transportation Research Forum. Doi: https://doi.org/10.22004/ag.econ.207723

Clark, G.L. 1997. Pension funds and urban investment: Four models of financial intermediation. Environment and Planning A 29 (7): 1297-1316. https://doi.org/10.1068/a291297.

Clark, G.L. 1998. Why convention dominates pension fund trustee investment decisionmaking. Environment and Planning A 30 (6): 997-1015. https://doi.org/10.1068/a300997.

Clark, G.L., and J. Evans. 1998. The private provision of urban infrastructure: financial intermediation through long-term contracts. Urban Studies 35 (2): 301-319. https://doi.org/10.1080/00420 98984998.

Clark, G.L., and A. Root. 1999. Infrastructure shortfall in the United Kingdom: the private finance initiative and government policy. Political Geography 18 (3): 341-365. https://doi.org/10.1016/ S0962-6298(98)00109-7.

Clark, G.L., A.H. Monk, R. Orr, and W. Scott. 2012. The new era of infrastructure investing. Pensions: An International Journal 17 (2): 103-111. https://doi.org/10.1057/pm.2012.10.

Clayton, J., J.N. Gordon, F.J. Fabozzi, S.M. Giliberto, Y. Liang, and S. Hudson-Wilson. 2007. Real estate comes of age. The Journal of Portfolio Management 33 (5): 15-26. https://doi.org/10.3905/ jpm.2007.698955.

Datz, G. 2013. Brazil's pension fund developmentalism. Competition \& Change 17 (2): 111-128. https://doi.org/10.1179/1024529413Z. 00000000029.

Dechant, T., and K. Finkenzeller. 2012a. Direct infrastructure investment and its role in drawdown-efficient portfolios.

Dechant, T., and K. Finkenzeller. 2012b. The role of infrastructure investments in a multi-asset portfolio-answers from dynamic asset allocation. Available at SSRN 1992520.

Dechant, T., and K. Finkenzeller. 2013. How much into infrastructure? Evidence from dynamic asset allocation. Journal of Property
Research 30 (2): 103-127. https://doi.org/10.1080/09599916. 2012.731075.

Della Croce, R., and J. Yermo. 2013. Institutional investors and infrastructure financing. Working Paper.

Della Croce, R., and S. Gatti. 2015. International trends in infrastructure finance. In Public private partnerships for infrastructure and business development, ed. S. Caselli, G. Corbetta, and V. Vecchi, 81-100. New York: Palgrave Macmillan.

Della Croce, R. 2011. Pension funds investment in infrastructure: Policy actions. OECD Working Papers on Finance, Insurance and Private Pensions, No. 13, OECD Publishing, Paris. https:// doi.org/10.1787/5kg272f9bnmx-en.

Della Croce, R. 2012. Trends in large pension fund investment in infrastructure. OECD Working Papers on Finance, Insurance and Private Pensions, No. 29, OECD Publishing, Paris. https://doi.org/ $10.1787 / 5 \mathrm{k} 8 \mathrm{xd} 1 \mathrm{p} 1 \mathrm{p} 7 \mathrm{r} 3$-en.

Dong, F., N. Chiara, and J. Vecer. 2010. Valuing callable and putable revenue-performance-linked project backed securities. International Journal of Theoretical and Applied Finance 13 (05): 751-765. https://doi.org/10.1142/S021902491000598X.

Ehlers, T. 2014. Understanding the challenges for infrastructure finance. Working Paper.

Eke, O.P., L.U. Okoye, and A.E. Omankhanlen. 2021. Can pension reforms moderate inflation expectations and spur savings? Evidence from Nigeria. WSEAS TRANSACTIONS on BUSINESS and ECONOMICS 18: 324-337.

Finkenzeller, K., T. Dechant, and W. Schäfers. 2010. Infrastructure: a new dimension of real estate? An asset allocation analysis. Journal of Property Investment \& Finance 28 (4): 263-274. https://doi.org/10.1108/14635781011058875.

Gabor, D. 2021. The wall street consensus. Development and Change 52 (3): 429-459. https://doi.org/10.1111/dech.12645.

Gatzert, N., and T. Kosub. 2016. Insurers' investment in infrastructure: Overview and treatment under Solvency II. The Geneva Papers. https://doi.org/10.1007/978-1-137-57479-4_4.

Gatzert, N., and T. Kosub. 2017. The impact of European initiatives on the treatment of insurers' infrastructure investments under solvency II. The Geneva Papers on Risk and InsuranceIssues and Practice 42 (4): 708-731. https://doi.org/10.1057/ s41288-017-0042-7.

Gawlitta, M., and J. Kleinow. 2015. Analysis of infrastructure financing by debt funds in the EU. In Proceedings of the Institution of Civil Engineers-Management, Procurement and Law, pp. $12-21$.

Gharaibeh, O.K. 2019. Optimal portfolio selection based on Jordanian infrastructure sub-index returns. International Journal of Scientific \& Technology Research 8 (12): 2560-2566.

Glänzel, W. 2003. Bibliometrics as a research field: A course on theory and application of bibliometric indicators.

Greer, R.J. 1997. What is an asset class, anyway?. Journal of Portfolio Management 23 (2): 86-91.

Hartigan, L.R., R. Prasad, and A.J. De Francesco. 2011. Constructing an investment return series for the UK unlisted infrastructure market: estimation and application. Journal of Property Research 28 (1): 35-58. https://doi.org/10.1080/09599916.2011.544148.

Hasnat, T. 2021. Infrastructure equity and firm performance in India. Millennial Asia 12 (1): 97-115. https://doi.org/10.1177/09763 99620948318.

Henn, L., K. Sloan, M.B. Charles, and N. Douglas. 2016. An appraisal framework for evaluating financing approaches for public infrastructure. Public Money \& Management 36 (4): 273-280. https:// doi.org/10.1080/09540962.2016.1162595.

Inderst, G. 2010a. Infrastructure as an asset class. EIB Papers 15 (1): 70-104. 
Inderst, G. 2010. Pension fund investment in infrastructure: What have we learnt?. Pensions: An International Journal 15 (2): 89-99. https://doi.org/10.1057/pm.2010.4.

Inderst, G., and F. Stewart. 2014a. Institutional investment in infrastructure in emerging markets and developing economies. Working Paper.

Inderst, G., and F. Stewart. 2014b. Institutional investment in infrastructure in developing countries: Introduction to potential models. Working Paper.

Inderst, G. 2009. Pension Fund Investment in Infrastructure. Working Paper.

Inderst, G. 2016. Infrastructure investment, private finance, and institutional investors: Asia from a global perspective. Working Paper.

Inderst, G. 2020. Social Infrastructure Finance and Institutional Investors. A Global Perspective. Working Paper.

Jones, A.W. 2015. Perceived barriers and policy solutions in clean energy infrastructure investment. Journal of Cleaner Production 104: 297-304. https://doi.org/10.1016/j.jclepro.2015.05.072.

Jones, M.V., N. Coviello, and Y.K. Tang. 2011. International entrepreneurship research (1989-2009): A domain ontology and thematic analysis. Journal of Business Venturing 26 (6): 632-659. https:// doi.org/10.1016/j.jbusvent.2011.04.001.

Kalmykov, V. 2015. Investment mechanisms of pension insurance and their role in development of national economy. Mediterranean Journal of Social Sciences 6 (1 S3): 50.

Ketterer, J., and A. Powell. 2018. Financing Infrastructure: on the quest for an asset class. Documento de discusión IDB-DP-622. Washington, DC: Banco Interamericano de Desarrollo.

Kumar, A., V. Srivastava, and M.I. Tabash. 2021. Infrastructure project finance: A systematic literature review and directions for future research. Qualitative Research in Financial Markets 13 (3): 295-327. https://doi.org/10.1108/QRFM-07-2020-0130.

Kumari, A., and A.K. Sharma. 2017. Infrastructure financing and development: A bibliometric review. International Journal of Critical Infrastructure Protection 16: 49-65. https://doi.org/10. 1016/j.ijcip.2016.11.005.

Kupperman, D., and S. Kilgallen. 2015. The case for liquid alternatives in defined-contribution plans. The Journal of Alternative Investments 17 (3): 59-66. https://doi.org/10.3905/jai.2014.17.3.059.

Lee, C. 2019. Financing method for real estate and infrastructure development using Markowitz's portfolio selection model and the Monte Carlo simulation. Engineering, Construction and Architectural Management 26 (9): 2008-2022. https://doi.org/ 10.1108/ECAM-10-2018-0440.

Lima, S., A. Brochado, and R.C. Marques. 2021. Public-private partnerships in the water sector: A review. Utilities Policy 69: 101182. https://doi.org/10.1016/j.jup.2021.101182.

Liñán, F., and A. Fayolle. 2015. A systematic literature review on entrepreneurial intentions: citation, thematic analyses, and research agenda. International Entrepreneurship and Management Journal 11 (4): 907-933. https://doi.org/10.1007/s11365-015-0356-5.

Little, R.G. 2010. Toward a new federal role in infrastructure investment: Using US sovereign wealth to rebuild America. Public Works Management \& Policy 14 (3): 288-306. https://doi.org/ 10.1177/1087724X09359911.

Littlechild, S. C. 1983. Regulation of British Telecommunications' profitability: report to the Secretary of State, February 1983. Department of Industry.

Lu, Z., F. Peña-Mora, S.Q. Wang, T. Liu, and D. Wu. 2019. Assessment framework for financing public-private partnership infrastructure projects through asset-backed securitization. Journal of Management in Engineering 35 (6): 04019027. https://doi.org/10.1061/ (ASCE)ME.1943-5479.0000708.

Machete, I., and R. Marques. 2021. Financing the water and sanitation sectors: A hybrid literature review. Infrastructures 6 (1): 9. https://doi.org/10.3390/infrastructures6010009.
Macpherson, A., and R. Holt. 2007. Knowledge, learning and small firm growth: A systematic review of the evidence. Research Policy 36 (2): 172-192. https://doi.org/10.1016/j.respol.2006. 10.001 .

Magweva, R., and M. Sibanda. 2020. Inflation and infrastructure sector returns in emerging markets-panel ARDL approach. Cogent Economics \& Finance 8 (1): 1730078. https://doi.org/10.1080/ 23322039.2020 .1730078$.

Majumder, S.B. 2021. Return and volatility spillovers among the thematic indices in India. Global Business Review. https://doi.org/ 10.1177/0972150921995476.

Martin, G.A. 2010. The long-horizon benefits of traditional and new real assets in the institutional portfolio. The Journal of Alternative Investments 13 (1): 6-29. https://doi.org/10.3905/jai.2010. 13.1.006.

Marzuki, M.J., and G. Newell. 2021a. The investment opportunities in the innovation-led listed satellite and telecommunication infrastructure sectors. Journal of Property Investment \& Finance 39 (3): 223-238. https://doi.org/10.1108/JPIF-10-2019-0132.

Marzuki, M.J., and G. Newell. 2021b. A global investment opportunity in non-listed infrastructure for institutional investors. Journal of Property Investment \& Finance 39 (3): 239-255. https://doi.org/ 10.1108/JPIF-11-2019-0142.

Mirrlees-Black, J. 2014. Reflections on RPI-X regulation in OECD countries. Utilities Policy 31: 197-202. https://doi.org/10.1016/j. jup.2014.09.010.

Müllner, J. 2017. International project finance: Review and implications for international finance and international business. Management Review Quarterly 67 (2): 97-133.

Mulrow, C.D. 1994. Systematic reviews: Rationale for systematic reviews. BMJ 309 (6954): 597-599. https://doi.org/10.1136/ bmj.309.6954.597.

Newell, G., and C. Lin Lee. 2011. The impact of alternative assets on the role of direct property in Australian mixed-asset portfolios. Pacific Rim Property Research Journal 17 (4): 531-559. https:// doi.org/10.1080/14445921.2011.11104341.

Newell, G., and H.W. Peng. 2008a. The role of US infrastructure in investment portfolios. Journal of Real Estate Portfolio Management 14 (1): 21-34. https://doi.org/10.1080/10835547.2008. 12089795.

Newell, G., and H.W. Peng. 2008b. Assessing the significance of motivating factors and risk factors in infrastructure funds management. Pacific Rim Property Research Journal 14 (4): 399-411. https://doi.org/10.1080/14445921.2008.11104265.

Newell, G., K.W. Chau, and S.K. Wong. 2009. The significance and performance of infrastructure in China. Journal of Property Investment \& Finance 27 (2): 180-202. https://doi.org/10.1108/ 14635780910937863.

Newell, G., H.W. Peng, and A. De Francesco. 2011. The performance of unlisted infrastructure in investment portfolios. Journal of Property Research 28 (1): 59-74. https://doi.org/10.1080/09599 916.2011.544149.

O'Neill, P. 2017. Managing the private financing of urban infrastructure. Urban Policy and Research 35 (1): 32-43. https://doi.org/ 10.1080/08111146.2016.1235034.

Oberholzer, G., C. Markowitz, M. Pautz, J. Barnor, and N. Grobbelaar. 2018. Infrastructure as an asset class in Africa. The Global Economic Governance (GEG) Africa. Discussion Paper. http://www. gegafrica.org/item/860-infrastructure-as-an-asset-class-in-africa

OECD. 2015. Fostering investment in infrastructure - Lessons learned from OECD Investment policy reviews. OECD Publications, Paris. https://www.oecd.org/daf/inv/investment-policy/Foste ring-Investment-in-Infrastructure.pdf

Orr, R.J., and J.R. Kennedy. 2008. Highlights of recent trends in global infrastructure: New players and revised game rules. Transnational Corporations 17 (1): 99-133. 
Orski, C.K. 2008. Highway tolling has entered the mainstream. Public Works Management \& Policy 12 (4): 548-550. https://doi.org/ 10.1177/1087724X08317110.

Oyedele, J.B. 2014. Performance and significance of UK-listed infrastructure in a mixed-asset portfolio. Journal of European Real Estate Research 7 (2): 199-215. https://doi.org/10.1108/ JERER-08-2013-0015.

Oyedele, J.B., S. McGreal, A. Adair, and P. Ogedengbe. 2013. Performance and role of European listed infrastructure in a mixedasset portfolio. Journal of Financial Management of Property and Construction 18 (2): 160-183. https://doi.org/10.1108/ JFMPC-07-2012-0022.

Oyedele, J.B., A. Adair, and S. McGreal. 2014. Performance of global listed infrastructure investment in a mixed asset portfolio. Journal of Property Research 31 (1): 1-25. https://doi.org/10.1080/ 09599916.2012 .737819$.

Page, S.N., D.W. Ankner, C. Jones, and R. Fetterman. 2008. The risks and rewards of private equity in infrastructure. Public Works Management \& Policy 13 (2): 100-113. https://doi.org/10.1177/ 1087724X08326311.

Panayiotou, A., and F. Medda. 2014. Attracting private sector participation in infrastructure investment: the UK case. Public Money \& Management 34 (6): 425-431. https://doi.org/10.1080/09540 962.2014.962369.

Peng, H.W., and G. Newell. 2007. The significance of infrastructure in Australian investment portfolios. Pacific Rim Property Research Journal 13 (4): 423-450. https://doi.org/10.1080/14445921. 2007.11104240.

Reddy, W. 2016. Alternative assets-a new challenge to property? An analysis of superannuation funds. Pacific Rim Property Research Journal 22 (2): 127-143. https://doi.org/10.1080/14445921. 2016.1203722 .

Regan, M. 2017. Capital markets, infrastructure investment and growth in the Asia Pacific region. International Journal of Financial Studies 5 (1): 5. https://doi.org/10.3390/ijfs5010005.

Roehrich, J.K., M.A. Lewis, and G. George. 2014. Are public-private partnerships a healthy option? A systematic literature review. Social Science \& Medicine 113: 110-119. https://doi.org/10. 1016/j.socscimed.2014.03.037.

Rothballer, C., and C. Kaserer. 2012. The risk profile of infrastructure investments: Challenging conventional wisdom. The Journal of Structured Finance 18 (2): 95-109. https://doi.org/10.3905/jsf. 2012.18.2.095

RREEF. 2005. Understanding infrastructure. https://www.oecd.org/ finance/private-pensions/42052208.pdf.

Satta, G., T. Notteboom, F. Parola, and L. Persico. 2017. Determinants of the long-term performance of initial public offerings (IPOs) in the port industry. Transportation Research Part a: Policy and Practice 103: 135-153. https://doi.org/10.1016/j.tra.2017.05. 032.

Savoia, J.R.F., J.R. Securato, D.R. Bergmann, and F.L. da Silva. 2019. Comparing results of the implied cost of capital and capital asset pricing models for infrastructure firms in Brazil. Utilities Policy 56: 149-158. https://doi.org/10.1016/j.jup.2018.12.004.

Sawant, R.J. 2010. Emerging market infrastructure project bonds: Their risks and returns. The Journal of Structured Finance 15 (4): 75-83. https://doi.org/10.3905/JSF.2010.15.4.075.

Sharma, R. and S. Y. 2012. Infrastructure: an emerging asset class for institutional investors. In The Societal Function of Investment Asset Classes: Implications for Responsible Investment Conference.

Siemiatycki, M. 2015. Canadian pension fund investors in transport infrastructure: A case study. Case Studies on Transport Policy 3 (2): 166-175. https://doi.org/10.1016/j.cstp.2015.01.002.

Singhal, S., G. Newell, and T.K. Nguyen. 2011. The significance and performance of infrastructure in India. Journal of Property
Research 28 (1): 15-34. https://doi.org/10.1080/09599916.2011. 544147.

Stevens, B., and P.A. Schieb. 2007. Infrastructure to 2030: Main findings and policy recommendations. Infrastructure to 2030 (19): i-510.

Thierie, W., and L. De Moor. 2016. The characteristics of infrastructure as an investment class. Financial Markets and Portfolio Management 30 (3): 277-297. https://doi.org/10.1007/ s11408-016-0273-9.

Thorpe, R., R. Holt, A. Macpherson, and L. Pittaway. 2005. Using knowledge within small and medium-sized firms: A systematic review of the evidence. International Journal of Management Reviews 7 (4): 257-281. https://doi.org/10.1111/j.1468-2370. 2005.00116.x.

Torrance, M. 2009a. Reconceptualizing urban governance through a new paradigm for urban infrastructure networks. Journal of Economic Geography 9 (6): 805-822. https://doi.org/10.1093/ jeg/lbn048.

Torrance, M. 2009b. The rise of a global infrastructure market through relational investing. Economic Geography 85 (1): 75-97. https:// doi.org/10.1111/j.1944-8287.2008.01004.x.

Tranfield, D., D. Denyer, and P. Smart. 2003. Towards a methodology for developing evidence-informed management knowledge by means of systematic review. British Journal of Management 14 (3): 207-222. https://doi.org/10.1111/1467-8551.00375.

Tricarico, A., and X. Sol. 2016. Re-building the world: The structural adjustment through mega-infrastructures in the era of financialization. Development 59: 53-58. https://doi.org/10.1057/ s41301-017-0082-0.

Urban Land Institute \& Ernst \& Young. 2013. Infrastructure 2013: Global priorities, global insights. http://uli.org/wp-content/uploa ds/ULI-Documents/Infrastructure-2013.pdf

Vassallo, J.M., T. Rangel, M. de los Ángeles BAEZA, and P.C. Bueno. 2018. The Europe 2020 project bond initiative: An alternative to finance infrastructure in Europe. Technological and Economic Development of Economy 24 (1): 229-252. https://doi.org/10. 3846/20294913.2016.1209251.

Vecchi, V., M. Hellowell, R. Della Croce, and S. Gatti. 2017. Government policies to enhance access to credit for infrastructure-based PPPs: An approach to classification and appraisal. Public Money \& Management 37 (2): 133-140. https://doi.org/10.1080/09540 962.2016.1266173.

Whiteside, H. 2017. The Canada infrastructure bank: private finance as poor alternative. Studies in Political Economy 98 (2): 223-237. https://doi.org/10.1080/07078552.2017.1343008.

Woetzel, J., N. Garemo, J. Mischke, P. Kamra, and R. Palter. 2017. Bridging infrastructure gaps: Has the world made progress. McKinsey \& Company. https://www.mckinsey.com.br/media/ McKinsey/Industries/Public and Social Sector/Our Insights/ Bridging infrastructure gaps has the world made progress/Bridg ing\%infrastructure-gaps-Discussion-paper.pdf

Wurstbauer, D., and W. Schäfers. 2015. Inflation hedging and protection characteristics of infrastructure and real estate assets. Journal of Property Investment \& Finance 33 (1): 19-44. https://doi. org/10.1108/JPIF-04-2014-0026.

Wurstbauer, D., S. Lang, C. Rothballer, and W. Schäfers. 2016. Can common risk factors explain infrastructure equity returns? Evidence from European capital markets. Journal of Property Research 33 (2): 97-120. https://doi.org/10.1080/09599916. 2016.1169211.

Publisher's Note Springer Nature remains neutral with regard to jurisdictional claims in published maps and institutional affiliations. 
Surbhi Gupta graduated in commerce from the Hindu College, University of Delhi, India, in 2014. She completed her master's in commerce in 2016 from the same college specializing in finance. In 2018, she joined the Department of Management Studies at the Indian Institute of Technology (IIT) Roorkee, India, as a Ph.D. candidate. Her current research is concerned with infrastructure financing through capital markets. Her major research interests include investment finance, alternative assets, and portfolio optimization. She can be contacted at sgupta2@bm.iitr.ac.in.

Anil Kumar Sharma a professor at the Department of Management Studies, IIT Roorkee is M. Com and M. Phil, First Class First, and Gold Medallist and Ph.D. in Financial Management from Panjab University, Chandigarh. He is working at IIT Roorkee for the past more than 20 years and has more than 25 years of teaching experience in total. His area of interest is finance $\&$ accounting and he has an equally good interest in research in the same area. He has published more than 140 research papers in International and National refereed journals and refereed conferences. He has guided $20 \mathrm{Ph}$.D. scholars and 15 scholars are currently working with him. One of his scholars has been awarded the prestigious Commonwealth Scholarship and Associate Fellowship for Higher Education Academy, UK. He along with one of his Ph.D. scholars has been awarded the best paper award for their paper presented at an international conference in Thailand. He is the chief editor of one International Journal, regional editor of one international journal, and editorial board member of five International and National Journals and reviewer to more than twenty international and National Journals of repute. Before joining IIT Roorkee in 2001, he had served three reputed Universities of the country. He is a registered consultant of Asian Development Bank, Manila, and Honorary Rosalind Member of London Journals Press. 